\title{
GYRFALCON POPULATION AND REPRODUCTION IN RELATION TO ROCK PTARMIGAN NUMBERS IN ICELAND
}

\author{
ÓLAFUR K. NieLSEN \\ Icelandic Institute of Natural History, Urriðaholtsstrati 6-8, P.O. Box 125, \\ 212 Garðabar, Iceland.E-mail: okn@ni.is
}

\begin{abstract}
I have studied the population ecology of the Gyrfalcon (Falco rusticolus) since 1981 on a $5,300-\mathrm{km}^{2}$ study area in northeast Iceland harbouring 83 traditional Gyrfalcon territories. The main questions addressed relate to the predator-prey relationship of the Gyrfalcon and its main prey, the Rock Ptarmigan (Lagopus muta). Specifically, how does the Gyrfalcon respond functionally and numerically to changes in ptarmigan numbers? Field work involved an annual census to determine occupancy of Gyrfalcon territories, breeding success, and food. Also, Rock Ptarmigan were censused annually on six census plots within the study area. The Rock Ptarmigan population showed multi-annual cycles, with peaks in 1986, 1998 and 2005. Cycle period was 11 or 12 years based on the 1981-2003 data. The Gyrfalcon in Iceland is a resident specialist predator and the Rock Ptarmigan is the main food in all years. The functional response curve was just slightly concave but ptarmigan densities never reached levels low enough to reveal the lower end of the trajectory. Occupancy rate of Gyrfalcon territories followed Rock Ptarmigan numbers with a 3-4 year time-lag. Gyrfalcons reproduced in all years, and all measures of Gyrfalcon breeding success - laying rate, success rate, mean brood size, and population productivity - were significantly related to March and April weather and to Rock Ptarmigan density. The Gyrfalcon data show characteristics suggesting that the falcon could be one of the forces driving the Rock Ptarmigan cycle (resident specialist predator, time-lag). The Iceland Gyrfalcon and Rock Ptarmigan data are the longest time series on the Gyrfalcon-Rock Ptarmigan relationship, and the only series that indicate a coupled predator-prey cycle for the falcon and its ptarmigan prey. Received 20 April 2011, accepted 28 July 2011.
\end{abstract}

NiELSEN, Ó. K. 2011. Gyrfalcon population and reproduction in relation to Rock Ptarmigan numbers in Iceland. Pages 21-48 in R. T. Watson, T. J. Cade, M. Fuller, G. Hunt, and E. Potapov (Eds.). Gyrfalcons and Ptarmigan in a Changing World, Volume II. The Peregrine Fund, Boise, Idaho, USA. http://dx.doi.org/10.4080/gpcw.2011.0210

Key words: Iceland, predator-prey relationship, time-lag, numerical response, functional response.

THE GyRFALCON (FALCO RUSTICOLUS) is a large diurnal raptor with a circumpolar, arctic and subarctic distribution (Cramp and Simmons 1980, Cade et al. 1998, Potapov and Sale 2005,
Booms et al. 2008). The breeding habitat is generally harsh, and winter conditions are such that in parts of its range the Gyrfalcon is migratory (Poole and Bromley 1988, Burnham 2007). In 
other parts, it is sedentary with just local movements of juvenile birds (Nielsen and Cade 1990a), and in between are partly migratory populations (Platt 1976). The Gyrfalcon is a specialized predator, and within most of its range the main food is one or two species of ptarmigan, the Willow Ptarmigan (Lagopus lagopus), and the Rock Ptarmigan (L. muta) (Figure 24.9. in Nielsen 2003). The Gyrfalcon is unusual among raptors that prey upon other birds; they go through the breeding season preying on the adult segment of the ptarmigan population at a time of year when ptarmigan abundance is lowest (Hagen 1952a, Cade 1960). The most common pattern among other diurnal raptors that prey upon birds is to time their breeding so that the period of peak food demand-the nestling period-coincides with fledging of their prey (Newton 1979, Newton and Marquiss 1982b) to capitalize on this annual peak in prey abundance. In contrast, it has been postulated that the timing of the Gyrfalcon's breeding period matches the dispersal period of juvenile Gyrfalcons with the annual peak in number of the most vulnerable ptarmigan (Cade 1960, Nielsen 2003). Ptarmigan chicks enter the diet of the Gyrfalcon when the ptarmigan are c. four weeks old, and it is only when they are c. 80 days old that they have grown their primaries and acquired full flying capabilities. In Iceland, this window of annual peak abundance of newly fledged, naïve Rock Ptarmigan with impaired flying capabilities lasts from late July to early September, coinciding with the dispersal period of juvenile Gyrfalcons.

Some ptarmigan populations, sympatric with Gyrfalcons, have multi-year, cyclic fluctuations of numbers. In Fennoscandia, the Willow Ptarmigan has traditionally had 3- to 7-year cycles (Myrberget 1984, Andrén et al. 1985, Angelstam et al. 1985), with 10-year cycles in the eastern part of Siberia and in North-America (Keith 1963, Bergerud 1970, Andreev 1988, Bergerud 1988). Rock Ptarmigan in Iceland (Nielsen and Pétursson 1995) and Alaska (Weeden and Theberge 1972) have c. 10-year cycles. Similar cycles are known for many other species of Arctic and boreal herbivores (Elton 1924, Keith 1963). Many believe these periodic fluctuations to be caused by trophic interactions (Berryman 2002), either between the herbivore and its food source (Bryant and Kuropat 1980, Bryant 1981b, Bryant 1981a), or the herbivore and its predators (Hanski et al. 1993, Krebs et al. 1995, Korpimäki and Krebs 1996, Turchin et al. 1999), or its pathogens (Berryman 1996, Hudson et al. 1998, Holmstad et al. 2005a, Holmstad et al. 2005b). It goes without saying that a specialist predator such as the Gyrfalcon, utilizing a cyclic prey base, is faced with greatly contrasting food regimes, alternating between years of plenty and scarcity. It has been assumed that these large scale changes in the Gyrfalcon's prey base are reflected in the population size and fecundity of the raptor (Palmer 1988, Cade et al. 1998, Booms et al. 2008).

Studies have been done on the Gyrfalcon-ptarmigan relationship in the Yukon Territory (Mossop and Hayes 1994) and the Northwest Territories (Shank and Poole 1994) of Canada, in two areas in Norway (Tømmeraas 1993, Selås and Kålås 2007), in Sweden (Nystrom et al. 2005), and in Iceland (Nielsen 1999). In Iceland, the numerical and functional response of the Gyrfalcon to changes in Rock Ptarmigan density was studied from 1981 to 1997 (Nielsen 1999). In this paper, I use these same data series extended to 2010 to describe how changes in Rock Ptarmigan density affect food composition of the Gyrfalcon, how populations of the two species relate to each other in time, and finally how Rock Ptarmigan numbers and weather interact with respect to fecundity of the Gyrfalcons.

\section{MeThods}

Study Area.-The study area covers $5,327 \mathrm{~km}^{2}$ located in northeast Iceland and centered on Lake Mývatn ( $\left.\mathrm{N} 65^{\circ} 60^{\prime}, \mathrm{W} 17^{\circ} 00^{\prime}\right)$. This area is characterized by rolling hills rising from the coast to $600-800 \mathrm{~m}$ above sea level at the southern border, $100 \mathrm{~km}$ inland. Several 
glaciated valleys, isolated mountains, and larger mountain masses break this relief (highest peak 1,222 $\mathrm{m}$ a.s.1.). Two major glacial rivers border the study area, Skjálfandafljót in the west, and Jökulsá á Fjöllum in the east.

The climate of Iceland is maritime with cool summers and mild winters. July is the warmest month and February the coldest. The mean temperature for these months respectively from $1981-2010$ on the study area was $9.5^{\circ} \mathrm{C}$ and $-1.0^{\circ} \mathrm{C}$ on the coast at Mánárbakki on Tjörnes Peninsula, and $10.6^{\circ} \mathrm{C}$ and $-3.7^{\circ} \mathrm{C}$ inland at Reykjahlíd, Lake Mývatn. Average annual precipitation decreases from the coast inland. It was $598 \mathrm{~mm}$ from 1981-2010 at Mánárbakki, and $464 \mathrm{~mm}$ at Reykjahlío. At Lake Mývatn, the last frost in spring on average was on 12 June, and the first frost in autumn was on 5 September (Eythorsson and Sigtryggsson 1971, Einarsson 1979, Icelandic Met Office http://www.vedur.is).

The dominant vegetation types are heath and meadow vegetation, which cover $3,003 \mathrm{~km}^{2}$. Other important types are wetlands of various kinds, $327 \mathrm{~km}^{2}$; Downy Birch (Betula pubescens) woods and shrubs, $156 \mathrm{~km}^{2}$; and moss heath, $2 \mathrm{~km}^{2}$. Sparsely- or un-vegetated land covers $1,659 \mathrm{~km}^{2}$, and lakes and rivers, 180 $\mathrm{km}^{2}$ (Vegetation map of Iceland, 1:500,000, Icelandic Institute of Natural History). Important heath plants include species belonging to the Ericaceae, the Dwarf Birch (Betula nana), the Tea-leaved Willow (Salix phylicifolia), and various species of grasses (Poaceae), sedges (Carex spp.), moss, and lichens. Three species of terrestrial mammals-Arctic Fox (Vulpes lagopus), Mink (Mustela vison) and Wood Mouse (Apodemus sylvaticus) - and 61 avian species breed in the area.

The avifauna is characterised by large populations of waders, waterfowl, and seabirds. In summer, the Rock Ptarmigan is common on heath and grassland habitats. Winter habitats include alpine areas, lava fields and birch shrubs (Nielsen 1993). Natural predators of adult Rock Ptarmigan are the Gyrfalcon, Raven (Corvus corax), Arctic Fox, and Mink. The Rock Ptarmigan is a game bird and is harvested in autumn; in 2010 the open season was 18 days from 29 October to 5 December. The Rock Ptarmigan is the only ptarmigan species breeding in Iceland.

Rock Ptarmigan Population.-Each spring, territorial Rock Ptarmigan cocks were counted on six plots within the Gyrfalcon study area. The combined size of these plots was $26.8 \mathrm{~km}^{2}$ (range 2.4-8.0 $\mathrm{km}^{2}$ ). Each plot was censused once during May (mean date 20 May, SD = 5.49 , range 7 May -6 June). The census was usually conducted by two observers in the late afternoon (time 17:00-24:00) or the early morning hours (time 05:00-10:00). The positions of territorial cocks were plotted on a map, as were the locations of all kills. A "kill" was the remains of a Rock Ptarmigan killed and eaten after arrival on the census plot in spring. The total number of cocks in spring was measured as the sum of the number of territorial cocks censused and killed (for a detailed description of census plots and methods, see Nielsen 1996). The Rock Ptarmigan index used for this study was the annual mean density of cocks on the six plots.

Gyrfalcon Population.-Gyrfalcons have traditional nesting territories (Tømmeraas 1993, Burnham et al. 2009). The term "nesting territory" refers to the area defended by the Gyrfalcons around the nest, usually only the nesting cliff and its immediate surroundings. The nesting territory was the unit surveyed in this study. Information on the location of Gyrfalcon nesting territories in the study area already existed at the start of the study in 1981, from local knowledge and the archives of the Icelandic Institute of Natural History (IINH). A nesting territory always had several nest sites. A "nest site" referred to the actual location of the nest. Nest sites belonging to the same nesting territory could be on different cliffs, with the territorial pair alternating between them in different years. Whether adjacent nest cliffs were 
regarded as belonging to the same nesting territory or not was based on their history of occupancy. By definition, only one Gyrfalcon pair could use a specific nesting territory at any one time. At the start of the study in the 1980s, there were 81 traditional Gyrfalcon nesting territories recognized in the study area (Nielsen 1986). By 2010 , there were 83 Gyrfalcon nesting territories recognized in the study area. Nest sites in two different nesting territories $(3.4$ and $4.2 \mathrm{~km}$ apart respectively), and used by the same banded females at the start of the study, have since been split among four pairs.

Field work was conducted between May and mid-August from 1981 to 2010. During the first visit in spring, the nesting territory was determined either as "unoccupied" if no signs of Gyrfalcons were found at any of the known nest sites, roosts, and perches within the territory, or "occupied" if definite signs of activity were observed. To be classified as occupied, the territory had to have a breeding pair, or in case of non-breeders, an active roost with some combination of bird sightings, new food remains, fresh droppings, moulted down and feathers, or pellets. Occupied territories could hold: (1) successful breeding pairs; (2) unsuccessful breeding pairs; (3) non-breeding pairs; and (4) unknown occupants. Successful pairs fledged at least one young. Unsuccessful pairs laid eggs but failed at some stage before fledging young; proof of breeding was observation of eggs or chicks, or an incubating adult. Territories with non-breeding pairs included territories where sightings were made of adult pairs or where proof was found of courtship feeding. Territories with unknown occupants included territories where clear signs of occupancy were found but no indications of courtship activities and only single birds observed. Classification into any of the four occupancy categories could be based on signs alone. Brood size was determined when the nestlings were 4-6 weeks old. Most of the nests were revisited after young had fledged. Nestlings found at that time, and dead since the last visit, where taken into account when calculating mean brood size.
I used the following variables to describe the relative size of the territorial Gyrfalcon population and its fecundity (cf. Newton and Marquiss 1982a, Steenhof et al. 1997, McIntyre and Adams 1999): (1) occupancy rate, the proportion of nesting territories surveyed that were occupied by Gyrfalcons; (2) laying rate, the proportion of occupied territories where eggs were laid; (3) success rate, the proportion of laying pairs that fledged chicks; (4) mean brood size, the average brood size at fledging for successful pairs; and (5) population productivity, mean number of fledglings per occupied nesting territory, calculated as the product of variables no. 2, 3 and 4 above. Population data for 1993 were not included in the current analysis as only 48 territories were visited, the territories visited were not chosen randomly, and they were biased towards "good" territories.

Gyrfalcon Diet.-Gyrfalcons started to bring prey to the nesting territory at the onset of courtship feeding in the $2^{\text {nd }}$ half of March to the $1^{\text {st }}$ half of April. During courtship, laying, and incubation, prey remains accumulated at plucking locations within the territory some distance away from the nest site itself. These plucking sites were usually on top of the nesting cliff, on the slope below it, or on either rim if the nesting territory was centered within a gorge. It was only after the young had hatched that prey remains started to accumulate in the nest. During the nestling stage, most prey remains were found in the nest or at the bottom of the cliffs below it. When the young fledged, they used many of the same plucking locations as their parents' in spring, but also many new sites so prey remains were much more spread out than in spring.

The food study was based on collections of prey remains and pellets from successful nesting territories only. Nest sites were visited two or three times during the summer to collect remains. The final visit was always made after young had fledged. Prey collections from territories with aborted breeding attempts were excluded from this analysis, as were prey col- 
lections from successful territories where collecting was not possible within the nest itself. These exclusions were made because of predictable changes in prey selection over the course of a season (Nielsen 2003). The only way to have comparable samples of diet was to collect prey remains at all sites where they accumulated, and over the course of the entire breeding season, courtship through fledging. Complete prey collections were made at 71 nesting territories, representing 521 successful breeding attempts. A total of 45,014 individuals were identified in the prey collections.

A prey collection consisted mostly of skeletal remains, but also feathers and pellets. Identification of most prey items was done in the field. Problematic specimens were brought back to the lab and identified with the aid of a reference collection. Each prey collection was separated into species and age groups, and the minimum number of individuals belonging to each group found by counting the most frequently occurring bone representing one individual. For the Rock Ptarmigan, this was nearly always the sternum (Langvatn 1977), but for smaller species this item was more often either one of the wings or the feet. Feather pattern or bone structure was used to distinguish between young of the year and adults. Pellets were only analysed for legs and bones of small birds, mainly young waders and passerines. Masses of prey items were taken from IINH files, and Nielsen (1986, unpubl. data).

Gyrfalcon Functional Response.-The number of adult Rock Ptarmigan consumed by Gyrfalcons during the breeding season (PC) was calculated using the formula:

$$
P C=\frac{(F C+M C+Y C) \times P G D}{W G \times 100}
$$

where $\mathrm{FC}=$ consumption by female Gyrfalcons $=$ number of females $\times 111$ days (the length of breeding season) $\times$ daily food requirements $\left(301 \mathrm{~g} \mathrm{day}^{-1}\right)$; $\mathrm{MC}=$ consumption by male Gyr- falcons $=$ number of males $\times 111$ days $\times$ daily food requirements $\left(241 \mathrm{~g} \mathrm{day}^{-1}\right)$; YC $=$ consumption by young $=54$ days $\times$ daily food requirements $\left(169 \mathrm{~g} \mathrm{day}^{-1}\right)$; PGD $=$ proportion of adult Rock Ptarmigan biomass in the diet of Gyrfalcons; WG = mean weight of Rock Ptarmigan in spring $537 \mathrm{~g}$ (unpubl. data). The per capita consumption was calculated by dividing PC by the total number of falcons. It was assumed that all territories were occupied by pairs. Daily food requirements were calculated in accordance with Lindberg (1983). These figures included waste (estimated at $20 \%$ ), and gross energy intake (estimated assimilation efficiency $70 \%$ ). Daily energy expenditure was taken as $2.5 \times$ basal metabolic rate $(B M R)$ for adults and $1.7 \times \mathrm{BMR}$ for young. Weights used for calculations of BMR were $1,355 \mathrm{~g}$ for adult males, $1,831 \mathrm{~g}$ for adult females, 1,262 $\mathrm{g}$ for young males and 1,573 $\mathrm{g}$ for young females (Cade et al. 1998). The sex ratio of young was taken to be equal (Nielsen 1986), and consumption by young used in the calculations was the average value for the two sexes. The breeding season as represented by the food data was taken as 111 days long, including 14 days for courtship, 43 days for laying and incubation, 47 days for nestling period, and seven days post-fledging period. Both the courtship-period and the post-fledging period were longer than stated above. I used a conservative estimate of what fraction of those periods my food collections covered, namely the last two weeks of the courtship period and the first week of the post-fledging period. It was assumed that the estimated number of prey items consumed equalled the number hunted, i.e., there was no surplus killing. The data, per capita consumption, was graphed against Rock Ptarmigan densities and the Holling's type two functional response function (Holling 1959) was fitted to the data using the solver application in Excel (Liengme 2000).

Weather.-Weather data used in the analysis was collected during the years 1981-2010 at six weather stations within or bordering the study area (courtesy of the Icelandic Met 
Office http://www.vedur.is/). The stations were: Grímsstaðir, Mánárbakki, Mýri, Mývatn, Möðrudalur, and Staðarhóll. The weather variables studied were for the months January through April, or for the following combinations of months: January and February, January through March, January through April, February and March, February through April, and March and April. The variables were: (1) mean temperature $\left({ }^{\circ} \mathrm{C}\right)$; (2) accumulated precipitation (mm); (3) days with wind $\geq 18 \mathrm{~m}$ per sec; (4) days with precipitation $\geq 1 \mathrm{~mm}$; (5) days with precipitation as snow; (6) days with $100 \%$ snow cover; and (7) mean percentage snow cover.

Statistical Analysis. - All statistical tests were run using the software STATISTICA (http://www.statsoft.com/). Statistical significance level was set at $\mathrm{P} \leq 0.05$ for all tests. I used ANOVA to test for differences in Rock Ptarmigan density among years ( 6 observations $\times 30$ years) and among decades (60 observations $\times 3$ decades). The variance was homogenous (Levene test, $\mathrm{F}_{29,150}=1.206, \mathrm{P}=$ 0.233 ), but the distribution was right-skewed and did not conform to normality. I used the natural logarithm (ln) to transform density values prior to analysis to normalize the frequency distribution. I used Chi-square to test for differences in occupancy rate, laying rate, and success rate among years. For success rate, cells (years) with fewer than five observations were added to adjacent cells prior to analysis. To test for differences in mean brood size among years I used ANOVA. To test for a relationship between occupancy rate, laying rate or success rate as dependent variables, and spring Rock Ptarmigan density and spring weather as explanatory variables, I used a logit regression with binomial distribution and logit link function (Hill and Lewicki 2006). For model selection I used "best subset," and the AIC criteria to select amongst models. Wald statistics were used to test the significance of the regression coefficients. Forward stepwise multiple linear regression was used to test for a relationship between mean brood size or population productivity (dependent variables), and spring Rock Ptarmigan density and spring weather (explanatory variables) (Hill and Lewicki 2006). The linear regression was evaluated with the F-test, and model parameters with the t-test. I used autocorrelation and partial autocorrelation, a time series analysis technique, to study the lag process in the Rock Ptarmigan time series (Chatfield 1989). Autocorrelation measured the degree of association between numbers in a time series. Autocorrelation coefficients plotted against their lag gave the autocorrelation function that provided an objective estimate of the dominant cycle period. Partial autocorrelation gave the correlation between current population and the population at some time in the future, but controlled for years between the points. Partial autocorrelation coefficients plotted against the lag gave the partial autocorrelation function and revealed the process order or the number of lags needed to model the population fluctuations. Similarly, I applied cross-correlations to assess the degree of temporal synchrony of the Rock Ptarmigan population and the Gyrfalcon occupancy rate, laying rate, and importance of Rock Ptarmigan in Gyrfalcon diet (Chatfield 1989). Correlation coefficients, $r_{t}$, were calculated with different time-lags, t. Correlation coefficients calculated between synchronously fluctuating parameters yielded high positive values with $t=0$ years, and rapidly decaying values with an increasing time-lag. Non-synchronous parameters did not correlate strongly. Fluctuating parameters in opposite phases yielded high negative correlation with $\mathrm{t}=0$ years. Prior to analysis, time series were detrended using trend subtract $(x=x-(a+b$ $x \mathrm{t})$ ) in the Time Series module, and standardized to zero mean and unit variance. Data points for 1993 were interpolated using adjacent values. 


\section{RESULTS}

Rock Ptarmigan Numbers.-Rock Ptarmigan densities in spring varied significantly among years $\left(\mathrm{F}_{29,150}=3.159, \mathrm{P}<0.001\right)$. During the years 1981-2003 there were two cycles of Rock Ptarmigan numbers with peaks in abundance in 1986 and 1998 (Figure 1). The difference between highest (1986) and lowest (2003) mean annual density observed was 5.4fold. The cyclic nature of these changes was further revealed by the autocorrelation function, which suggested a cycle period of 11-12 years (Figure 2b). The partial autocorrelation function gave a more detailed description of the lag process involved, which in this case was a negative 4-year lag (Figure 2a). The dynamics of the Rock Ptarmigan population changed with the closure of the game bird hunting season in the autumn of 2003 and 2004 , resulting in a peak in 2005, seven years after the peak in 1998. There was a significant difference in mean Rock Ptarmigan density between the three decades of the study $\left(\mathrm{F}_{2,177}\right.$ $=12.300, \mathrm{P}<0.001)$; the high numbers in 1998 and 2005 were $65 \%$ of the 1986 peak, and mean densities in 1991-2000 and 2001-2010 were $56 \%$ and $61 \%$ respectively of the mean density in 1981-1990.

Gyrfalcon Food Habits and Functional Response.-A total of 59 bird species, two mammal species and one fish were found in the Gyrfalcon prey remains. Adult Rock Ptarmigan were the most important food item in all years, with a mean importance of $66.9 \%$ (range $41.0-84.4 \%$ ) and 67.8\% (39.8-86.0\%) of prey numbers and prey biomass respectively (Tables 1 and 2). Other important prey groups were waterfowl, alcids, and shorebirds (Tables 1 and 2). A cross-correlation analysis of annual Rock Ptarmigan density lagged by the importance of Rock Ptarmigan in the Gyrfalcon's diet, expressed either as a percentage of prey number or biomass, was significant $(\mathrm{P}<0.05)$ for both data sets with no time-lag. Thus, Rock Ptarmigan were the main prey of the Gyrfalcon in all years, and change in the importance of

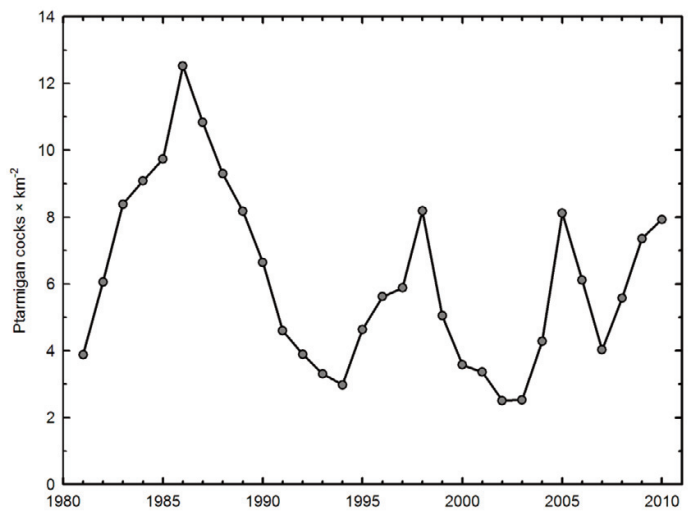

Figure 1. Changes in density of Rock Ptarmigan in the Gyrfalcon study area in northeast Iceland 1981-2010. Densities are mean values from six census plots.
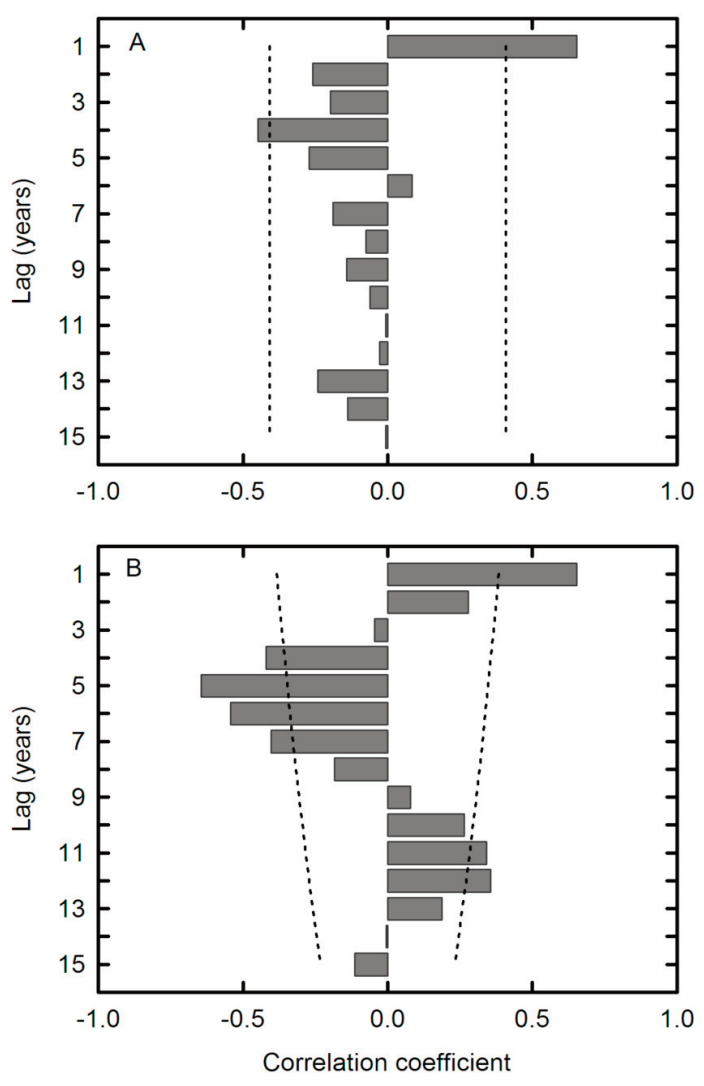

Figure 2. Partial autocorrelation function (a) and autocorrelation function (b) for spring densities of Rock Ptarmigan in northeast Iceland 1981-2003. 
Table 1. Food habits of Gyrfalcons in northeast Iceland 1981-2010. Importance of prey is expressed as percent of the total number of prey items identified each year.

\begin{tabular}{|c|c|c|c|c|c|c|c|c|c|c|c|}
\hline ঠ & 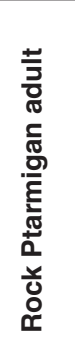 & 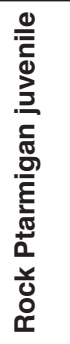 & $\begin{array}{l}\bar{z} \\
0 \\
\frac{t}{ \pm} \\
\frac{\pi}{\pi} \\
3\end{array}$ & $\begin{array}{l}\text { o } \\
\frac{\overline{0}}{0} \\
\frac{0}{0} \\
\frac{0}{0}\end{array}$ & $\frac{0}{\frac{0}{0}}$ & 옴 & 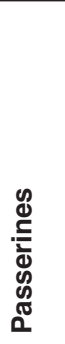 & $\begin{array}{l}\text { ঠे } \\
\stackrel{\Xi}{0}\end{array}$ & $\begin{array}{l}\bar{\pi} \\
\text { 음 }\end{array}$ & 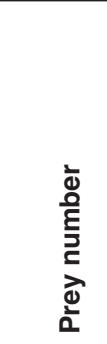 & $\begin{array}{l}\stackrel{n}{\Delta} \\
\stackrel{\Delta}{\mathbf{d}}\end{array}$ \\
\hline 1981 & 71.7 & 0.2 & 14.8 & 5.6 & 5.1 & 2.3 & 0.4 & 0.0 & 100.0 & 1,708 & 15 \\
\hline 1982 & 76.7 & 0.1 & 14.2 & 4.2 & 3.6 & 1.2 & 0.0 & 0.0 & 100.0 & 1,603 & 15 \\
\hline 1983 & 84.4 & 0.1 & 6.6 & 3.1 & 3.8 & 1.8 & 0.1 & 0.0 & 100.0 & 738 & 9 \\
\hline 1984 & 78.3 & 1.4 & 9.3 & 5.6 & 3.8 & 1.1 & 0.2 & 0.3 & 100.0 & 1,780 & 19 \\
\hline 1985 & 82.1 & 1.3 & 11.0 & 2.4 & 2.0 & 0.7 & 0.1 & 0.3 & 100.0 & 2,755 & 29 \\
\hline 1986 & 81.2 & 1.8 & 8.0 & 2.8 & 4.5 & 1.5 & 0.1 & 0.1 & 100.0 & 1,411 & 15 \\
\hline 1987 & 71.3 & 2.5 & 11.1 & 5.7 & 5.2 & 3.0 & 0.6 & 0.6 & 100.0 & 2,656 & 31 \\
\hline 1988 & 66.4 & 5.4 & 12.9 & 8.9 & 2.4 & 2.5 & 1.0 & 0.5 & 100.0 & 1,966 & 20 \\
\hline 1989 & 79.1 & 0.9 & 10.2 & 4.0 & 0.8 & 3.4 & 1.5 & 0.1 & 100.0 & 2,374 & 25 \\
\hline 1990 & 70.3 & 3.6 & 9.5 & 8.4 & 3.4 & 3.2 & 1.3 & 0.3 & 100.0 & 1,443 & 17 \\
\hline 1991 & 64.2 & 1.3 & 14.7 & 8.5 & 3.1 & 5.2 & 2.3 & 0.8 & 100.0 & 620 & 11 \\
\hline 1992 & 50.7 & 1.5 & 22.6 & 12.1 & 7.1 & 3.9 & 1.8 & 0.4 & 100.0 & 1,712 & 23 \\
\hline 1993 & 56.2 & 0.8 & 18.7 & 14.5 & 5.7 & 3.3 & 0.6 & 0.2 & 100.0 & 1,077 & 17 \\
\hline 1994 & 57.1 & 3.0 & 17.7 & 11.5 & 6.0 & 2.4 & 2.1 & 0.1 & 100.0 & 1,279 & 13 \\
\hline 1995 & 64.5 & 0.8 & 16.6 & 11.2 & 3.4 & 2.1 & 1.2 & 0.1 & 100.0 & 1,832 & 20 \\
\hline 1996 & 59.4 & 0.7 & 18.2 & 9.6 & 4.5 & 6.3 & 1.0 & 0.3 & 100.0 & 1,439 & 15 \\
\hline 1997 & 68.2 & 0.4 & 17.1 & 7.4 & 3.4 & 2.9 & 0.4 & 0.2 & 100.0 & 1,641 & 19 \\
\hline 1998 & 72.0 & 0.9 & 9.8 & 6.5 & 9.0 & 1.7 & 0.1 & 0.1 & 100.0 & 1,607 & 17 \\
\hline 1999 & 58.0 & 7.6 & 12.3 & 7.1 & 11.7 & 2.6 & 0.3 & 0.3 & 100.0 & 924 & 12 \\
\hline 2000 & 65.0 & 3.0 & 20.6 & 5.1 & 4.7 & 1.1 & 0.5 & 0.0 & 100.0 & 1,248 & 17 \\
\hline 2001 & 41.0 & 1.3 & 30.9 & 8.2 & 13.4 & 4.1 & 0.9 & 0.1 & 100.0 & 685 & 11 \\
\hline 2002 & 59.9 & 1.4 & 24.4 & 7.1 & 4.2 & 2.1 & 0.8 & 0.0 & 100.0 & 716 & 10 \\
\hline 2003 & 60.5 & 0.7 & 21.8 & 8.5 & 4.9 & 2.9 & 0.6 & 0.1 & 100.0 & 1,604 & 20 \\
\hline 2004 & 58.9 & 0.8 & 21.4 & 10.9 & 3.1 & 4.2 & 0.6 & 0.1 & 100.0 & 1,553 & 20 \\
\hline 2005 & 71.5 & 1.2 & 14.3 & 9.1 & 1.0 & 1.2 & 1.6 & 0.1 & 100.0 & 1,932 & 22 \\
\hline 2006 & 57.5 & 0.5 & 25.2 & 6.3 & 6.6 & 3.4 & 0.2 & 0.3 & 100.0 & 647 & 9 \\
\hline 2007 & 60.3 & 0.2 & 15.8 & 7.2 & 10.8 & 4.9 & 0.4 & 0.3 & 100.0 & 1,760 & 17 \\
\hline 2008 & 49.0 & 1.7 & 24.3 & 10.7 & 10.0 & 3.3 & 1.0 & 0.1 & 100.0 & 1,211 & 18 \\
\hline 2009 & 54.2 & 1.6 & 17.0 & 12.4 & 12.8 & 1.6 & 0.3 & 0.0 & 100.0 & 1,481 & 18 \\
\hline 2010 & 66.1 & 1.1 & 19.4 & 4.9 & 6.6 & 1.4 & 0.4 & 0.2 & 100.0 & 1,612 & 17 \\
\hline Total & 66.9 & 1.6 & 15.5 & 7.4 & 5.1 & 2.6 & 0.7 & 0.2 & 100.0 & 45,014 & 521 \\
\hline
\end{tabular}


Table 2. Food habits of Gyrfalcons in northeast Iceland 1981-2010. Importance of prey is expressed as a percent of biomass of prey items identified each year.

\begin{tabular}{|c|c|c|c|c|c|c|c|c|c|c|}
\hline 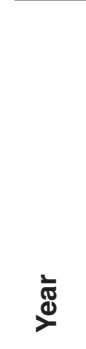 & 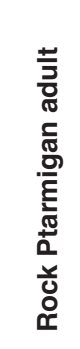 & 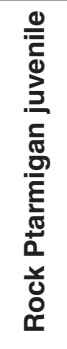 & $\begin{array}{l}\bar{z} \\
0 \\
\frac{t}{0} \\
\frac{d}{\pi} \\
3\end{array}$ & 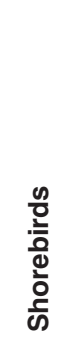 & $\frac{\frac{0}{0}}{\frac{0}{0}}$ & 告 & 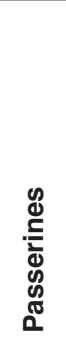 & $\begin{array}{l}\bar{\Xi} \\
\stackrel{ \pm}{0} \\
\end{array}$ & $\begin{array}{l}\bar{\Xi} \\
\stackrel{0}{\circ}\end{array}$ & 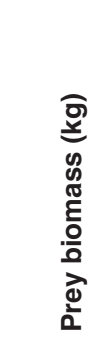 \\
\hline 1981 & 71.9 & 0.1 & 19.9 & 2.0 & 5.4 & 0.8 & 0.0 & 0.0 & 100.0 & 915 \\
\hline 1982 & 75.5 & 0.0 & 19.6 & 1.3 & 3.4 & 0.3 & 0.0 & 0.0 & 100.0 & 875 \\
\hline 1983 & 86.0 & 0.0 & 8.9 & 1.0 & 3.7 & 0.4 & 0.0 & 0.0 & 100.0 & 389 \\
\hline 1984 & 80.2 & 0.4 & 13.5 & 1.5 & 3.7 & 0.3 & 0.0 & 0.4 & 100.0 & 932 \\
\hline 1985 & 82.4 & 0.4 & 14.1 & 0.8 & 1.9 & 0.1 & 0.0 & 0.2 & 100.0 & 1,475 \\
\hline 1986 & 82.9 & 0.5 & 10.7 & 0.8 & 4.4 & 0.6 & 0.0 & 0.0 & 100.0 & 742 \\
\hline 1987 & 74.4 & 0.8 & 15.3 & 2.8 & 5.1 & 0.7 & 0.0 & 1.0 & 100.0 & 1,368 \\
\hline 1988 & 72.8 & 1.8 & 19.0 & 2.6 & 2.5 & 0.7 & 0.1 & 0.6 & 100.0 & 963 \\
\hline 1989 & 82.1 & 0.3 & 14.5 & 1.6 & 0.7 & 0.6 & 0.1 & 0.2 & 100.0 & 1,228 \\
\hline 1990 & 75.1 & 1.1 & 14.5 & 4.1 & 3.4 & 1.1 & 0.1 & 0.5 & 100.0 & 725 \\
\hline 1991 & 67.5 & 0.4 & 24.1 & 3.0 & 3.0 & 0.8 & 0.1 & 1.0 & 100.0 & 316 \\
\hline 1992 & 51.8 & 0.4 & 34.3 & 4.8 & 6.9 & 1.0 & 0.2 & 0.5 & 100.0 & 900 \\
\hline 1993 & 57.8 & 0.3 & 27.1 & 8.0 & 5.6 & 1.1 & 0.0 & 0.3 & 100.0 & 562 \\
\hline 1994 & 60.2 & 1.0 & 27.8 & 3.6 & 6.2 & 1.0 & 0.2 & 0.1 & 100.0 & 651 \\
\hline 1995 & 64.8 & 0.2 & 24.1 & 6.6 & 3.3 & 0.8 & 0.1 & 0.1 & 100.0 & 980 \\
\hline 1996 & 61.1 & 0.2 & 27.6 & 3.7 & 4.5 & 2.6 & 0.0 & 0.3 & 100.0 & 752 \\
\hline 1997 & 67.2 & 0.1 & 24.3 & 3.8 & 3.3 & 0.9 & 0.0 & 0.4 & 100.0 & 895 \\
\hline 1998 & 72.5 & 0.3 & 14.7 & 3.2 & 8.8 & 0.6 & 0.0 & 0.1 & 100.0 & 858 \\
\hline 1999 & 62.3 & 2.4 & 19.4 & 2.5 & 12.1 & 0.9 & 0.0 & 0.4 & 100.0 & 462 \\
\hline 2000 & 61.8 & 0.8 & 31.0 & 1.6 & 4.5 & 0.3 & 0.0 & 0.0 & 100.0 & 705 \\
\hline 2001 & 39.8 & 0.4 & 43.2 & 2.9 & 12.6 & 0.6 & 0.3 & 0.1 & 100.0 & 379 \\
\hline 2002 & 59.4 & 0.4 & 32.9 & 2.5 & 4.1 & 0.6 & 0.0 & 0.0 & 100.0 & 388 \\
\hline 2003 & 59.1 & 0.2 & 31.3 & 4.1 & 4.6 & 0.6 & 0.0 & 0.0 & 100.0 & 882 \\
\hline 2004 & 58.8 & 0.2 & 31.4 & 5.4 & 2.9 & 0.9 & 0.2 & 0.1 & 100.0 & 836 \\
\hline 2005 & 71.6 & 0.4 & 21.4 & 5.2 & 0.9 & 0.3 & 0.1 & 0.1 & 100.0 & 1,035 \\
\hline 2006 & 51.6 & 0.1 & 38.6 & 3.0 & 5.6 & 0.7 & 0.0 & 0.4 & 100.0 & 387 \\
\hline 2007 & 60.8 & 0.1 & 23.4 & 4.0 & 10.6 & 1.0 & 0.0 & 0.2 & 100.0 & 938 \\
\hline 2008 & 49.2 & 0.5 & 36.3 & 3.3 & 9.8 & 0.8 & 0.1 & 0.2 & 100.0 & 647 \\
\hline 2009 & 56.6 & 0.5 & 25.6 & 4.0 & 12.8 & 0.4 & 0.0 & 0.0 & 100.0 & 762 \\
\hline 2010 & 64.6 & 0.3 & 26.4 & 1.6 & 6.3 & 0.4 & 0.0 & 0.2 & 100.0 & 885 \\
\hline Total & 67.8 & 0.5 & 22.6 & 3.1 & 5.0 & 0.7 & 0.1 & 0.2 & 100.0 & 23,829 \\
\hline
\end{tabular}




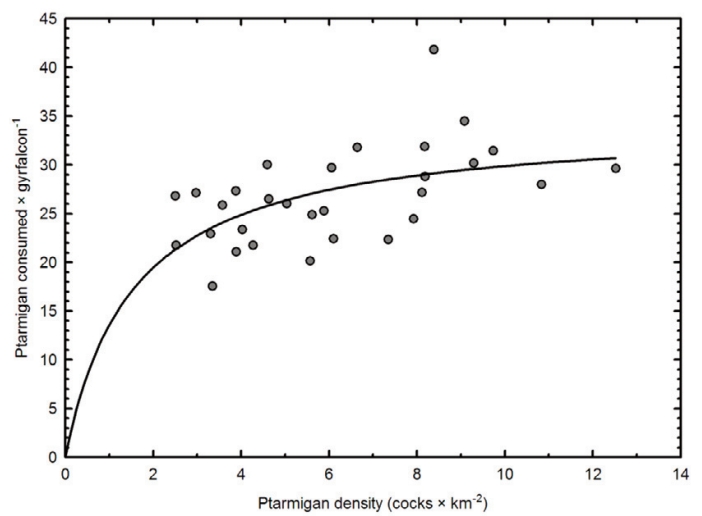

Figure 3. The functional response of Gyrfalcons to change in Rock Ptarmigan density, northeast Iceland 1981-2010. The fitted line is the Holling's type-two functional response curve $\left(R^{2}=0.27\right)$.

Table 3. Occupancy categories for Gyrfalcon territories in northeast Iceland 1981-2010.

\begin{tabular}{lcc}
\hline & Number & Percentage \\
Successful breeding pairs & 730 & 30.4 \\
Unsuccessful breeding pairs & 128 & 5.3 \\
Non-breeding pairs & 340 & 14.2 \\
Unknown occupants & 293 & 12.2 \\
Not active & 908 & 37.9 \\
\hline Total & 2,399 & 100 \\
\hline
\end{tabular}

Note: Successful pairs fledged at least one young. Unsuccessful pairs laid eggs but failed at some stage before fledging young; Territories with non-breeding pairs included territories where sightings were made of adult pairs or where proof was found of courtship feeding. Territories with unknown occupants included territories where clear signs of occupancy were found but no indications of courtship activities and only single birds observed.
Rock Ptarmigan in the Gyrfalcons' diet was correlated with Rock Ptarmigan density.

The functional response of Gyrfalcons to Rock Ptarmigan density, expressed as the number of Rock Ptarmigan consumed per Gyrfalcon over the breeding season, did not change much over the range of Rock Ptarmigan densities observed (Figure 3). It was only at the lower end of the observed Ptarmigan density that there was a slight indication of reduction in per capita Rock Ptarmigan consumption by Gyrfalcons.

Gyrfalcon Numbers: Territory Occupancy.The occupancy status of Gyrfalcon territories was determined for 2,399 territory years. Territories were occupied by Gyrfalcons in 1,491 $(62.2 \%)$ of territory years. Territories were most commonly occupied by successful breeding pairs $(30.4 \%)$, but other occupants included failed breeders, courting pairs, and unknown occupants (non-courting pairs or single birds) (Table 3 ).

The mean annual occupancy rate of Gyrfalcon territories was $61.9 \%$ (range 48.1-76.3\%) and varied significantly among years (Table $4 ; \chi^{2}=$ $57.44, \mathrm{df}=28, \mathrm{P}<0.001)$. The pattern of occupancy rate showed two distinct periods with peaks in 1987-1991 and 2001, and lows in 1981-1982, 1994-1996 and 2006-2007 (Figure 4a). In 2008-2010, the occupancy rate was increasing again.

The autocorrelation function for occupancy rate of Gyrfalcons gave a cosine-shaped trajectory with significant negative coefficients at six- and seven-year lags, indicating a 12-14 year cycle. The partial autocorrelation function showed a significant negative coefficient with a five-year lag. The two series, Rock Ptarmigan density and occupancy rate of Gyrfalcon territories, related to each other in time and showed a repetitive pattern, both rising and falling, with Gyrfalcons tracking Rock Ptarmigan (Figure 4a). The cross-correlation function for the two series showed that a high number of Gyrfalcons (= occupied territories) was pre- 
Table 4. Population parameters for Gyrfalcons in northeast Iceland, 1981-2010.

\begin{tabular}{|c|c|c|c|c|c|c|c|c|c|c|c|}
\hline む & 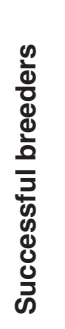 & 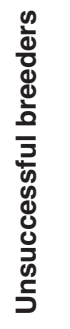 & 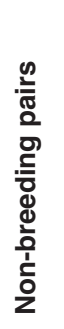 & 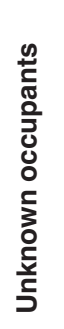 & 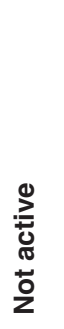 & 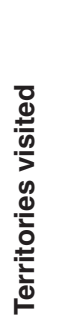 & 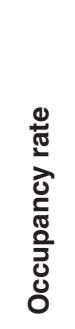 & 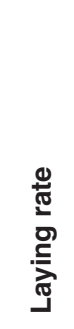 & 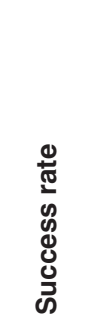 & 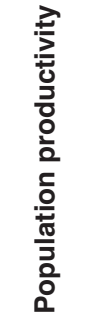 & 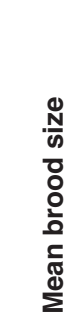 \\
\hline 1981 & 23 & 2 & 5 & 10 & 37 & 77 & 51.9 & 62.5 & 92.0 & 1.65 & 2.88 \\
\hline 1982 & 18 & 2 & 7 & 11 & 41 & 79 & 48.1 & 52.6 & 90.0 & 1.45 & 3.06 \\
\hline 1983 & 10 & 5 & 15 & 15 & 34 & 79 & 57.0 & 33.3 & 66.7 & 0.49 & 2.20 \\
\hline 1984 & 20 & 7 & 17 & 9 & 28 & 81 & 65.4 & 50.9 & 74.1 & 1.02 & 2.70 \\
\hline 1985 & 30 & 3 & 5 & 11 & 31 & 80 & 61.3 & 67.3 & 90.9 & 1.69 & 2.76 \\
\hline 1986 & 34 & 1 & 6 & 10 & 28 & 79 & 64.6 & 68.6 & 97.1 & 2.16 & 3.24 \\
\hline 1987 & 36 & 1 & 10 & 11 & 22 & 80 & 72.5 & 63.8 & 97.3 & 1.78 & 2.88 \\
\hline 1988 & 27 & 7 & 19 & 8 & 20 & 81 & 75.3 & 55.7 & 79.4 & 1.21 & 2.73 \\
\hline 1989 & 32 & 5 & 12 & 12 & 19 & 80 & 76.3 & 60.7 & 86.5 & 1.57 & 3.00 \\
\hline 1990 & 22 & 11 & 14 & 10 & 22 & 79 & 72.2 & 57.9 & 66.7 & 1.10 & 2.85 \\
\hline 1991 & 23 & 5 & 21 & 12 & 19 & 80 & 76.3 & 45.9 & 82.1 & 0.89 & 2.37 \\
\hline 1992 & 28 & 10 & 9 & 10 & 24 & 81 & 70.4 & 66.7 & 73.7 & 1.29 & 2.63 \\
\hline 1993 & 21 & 3 & 9 & 4 & 11 & 48 & $\ldots$ & $\ldots$ & $\ldots$ & $\ldots$ & 2.31 \\
\hline 1994 & 13 & 2 & 15 & 16 & 35 & 81 & 56.8 & 32.6 & 86.7 & 0.80 & 2.85 \\
\hline 1995 & 23 & 1 & 12 & 13 & 33 & 82 & 59.8 & 49.0 & 95.8 & 1.27 & 2.71 \\
\hline 1996 & 20 & 7 & 12 & 8 & 35 & 82 & 57.3 & 57.4 & 74.1 & 1.33 & 3.12 \\
\hline 1997 & 28 & 3 & 10 & 8 & 32 & 81 & 60.5 & 63.3 & 90.3 & 1.71 & 3.00 \\
\hline 1998 & 25 & 3 & 15 & 7 & 31 & 81 & 61.7 & 56.0 & 89.3 & 1.40 & 2.80 \\
\hline 1999 & 22 & 5 & 14 & 9 & 30 & 80 & 62.5 & 54.0 & 81.5 & 1.15 & 2.61 \\
\hline 2000 & 20 & 4 & 16 & 7 & 32 & 79 & 59.5 & 51.1 & 83.3 & 1.14 & 2.68 \\
\hline 2001 & 20 & 7 & 17 & 12 & 27 & 83 & 67.5 & 48.2 & 74.1 & 0.87 & 2.44 \\
\hline 2002 & 17 & 7 & 16 & 13 & 30 & 83 & 63.9 & 45.3 & 70.8 & 0.78 & 2.42 \\
\hline 2003 & 34 & 2 & 4 & 11 & 31 & 82 & 62.2 & 70.6 & 94.4 & 1.93 & 2.89 \\
\hline 2004 & 29 & 7 & 1 & 10 & 36 & 83 & 56.6 & 76.6 & 80.6 & 1.90 & 3.07 \\
\hline 2005 & 33 & 4 & 5 & 6 & 35 & 83 & 57.8 & 77.1 & 89.2 & 1.73 & 2.52 \\
\hline 2006 & 16 & 3 & 14 & 8 & 42 & 83 & 49.4 & 46.3 & 84.2 & 0.95 & 2.44 \\
\hline 2007 & 22 & 3 & 10 & 7 & 41 & 83 & 50.6 & 59.5 & 88.0 & 1.64 & 3.14 \\
\hline 2008 & 27 & 3 & 11 & 5 & 37 & 83 & 55.4 & 65.2 & 90.0 & 1.26 & 2.15 \\
\hline 2009 & 28 & 4 & 10 & 9 & 32 & 83 & 61.4 & 62.7 & 87.5 & 1.46 & 2.67 \\
\hline 2010 & 29 & 1 & 9 & 11 & 33 & 83 & 60.2 & 60.0 & 96.7 & 1.74 & 3.00 \\
\hline Mean & $\ldots$ & $\ldots$ & $\ldots$ & $\ldots$ & $\ldots$ & $\ldots$ & 61.9 & 57.3 & 84.6 & 1.36 & 2.74 \\
\hline SD & $\ldots$ & $\ldots$ & $\ldots$ & $\ldots$ & $\ldots$ & $\ldots$ & 7.8 & 10.9 & 9.0 & 0.40 & 0.29 \\
\hline CV & $\ldots$ & $\ldots$ & $\ldots$ & $\ldots$ & $\ldots$ & $\ldots$ & 12.6 & 19.0 & 10.7 & 29.6 & 10.5 \\
\hline
\end{tabular}

Note: in 1993, a smaller proportion of territories were visited than usual, $n=48$; further, the sample was biased towards "better" territories, and therefore is not used to calculate the different rates and population productivity for this study. SD=standard deviation. $C V=$ coefficient of variation. 

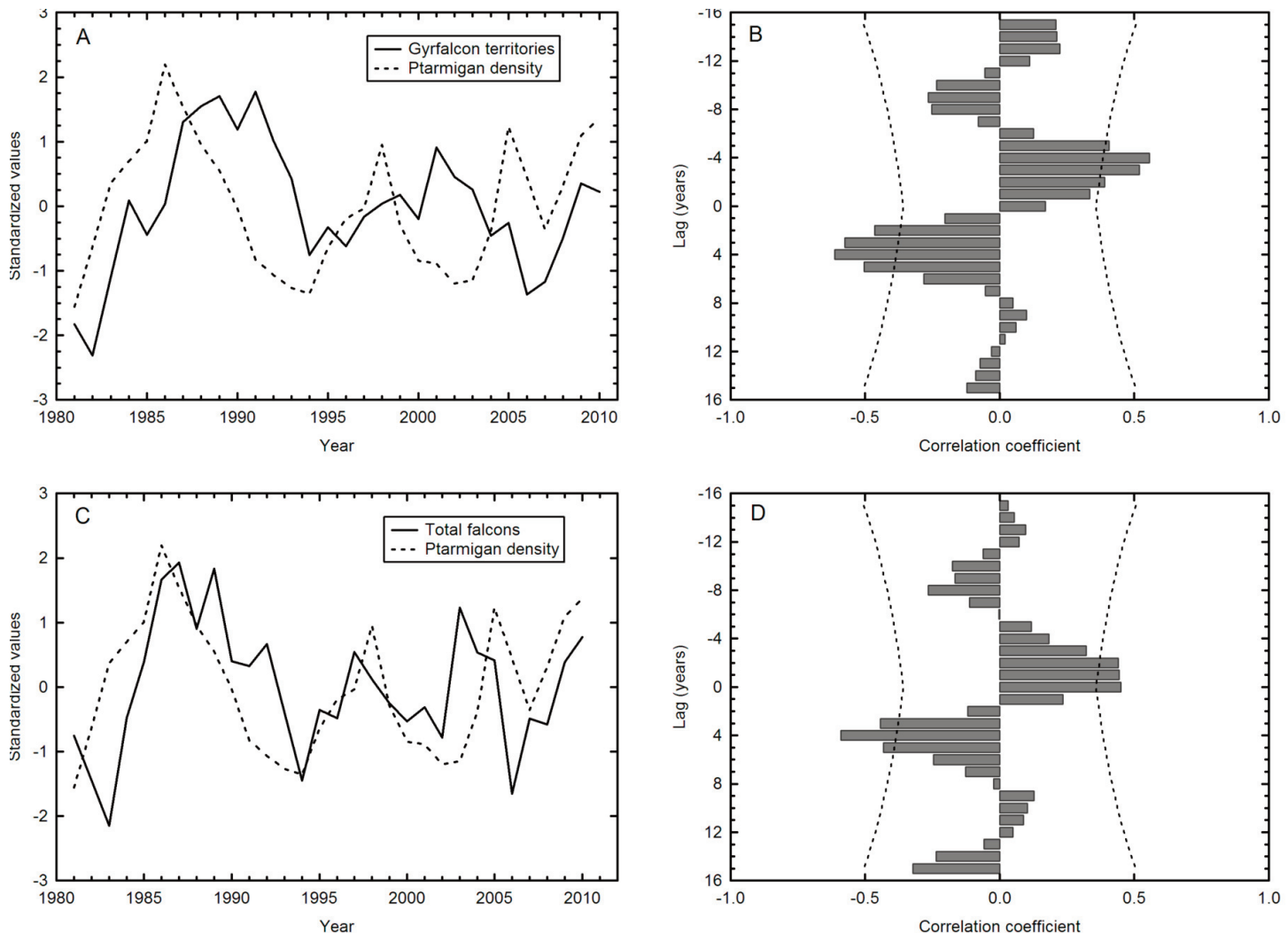

Figure 4. (A) Rock Ptarmigan density and occupancy rate of Gyrfalcon territories; the series are detrended and standardized. (B) Cross-correlation function for Rock Ptarmigan densities lagged by occupancy rate of Gyrfalcon territories. (C) Rock Ptarmigan density and total number of Gyrfalcons in late summer (sum of adults and fledglings). (D) Cross-correlation function for Rock Ptarmigan densities lagged by total number of Gyrfalcons (adults + fledglings). Northeast Iceland 1981-2010.

ceded by high numbers of Rock Ptarmigan two to five years previously, and succeeded by low numbers of Rock Ptarmigan two to five years into the future (Figure 4b).

Gyrfalcon Numbers: Reproduction.-Gyrfalcons reproduced in all years. The average annual laying rate was $57.3 \%$ (range $32.6-77.1 \%$ ), and varied significantly among years $\left(\chi^{2}=65.7, \mathrm{df}=28, \mathrm{p}<0.001\right.$; Table 4$)$. The average annual success rate was $84.6 \%$ (range 66.7-97.3\%), and showed significant inter-annual changes $\left(\chi^{2}=36.48, \mathrm{df}=16, \mathrm{P}=\right.$ 0.002 ; Table 4). Annual mean brood size averaged 2.74 fledglings per successful pair (range 2.15-3.24), and varied significantly among years $\left(\mathrm{F}_{29,618}=1.843, \mathrm{P}=0.005\right.$; Table 4$)$. Population productivity was 1.36 fledglings per occupied territory (range 0.49-2.16; Table 4). Population productivity was much more variable than mean brood size. There was a significant positive correlation between mean laying rate and brood size $(\mathrm{r}=0.39, \mathrm{P}=0.034)$, and these two variables determined to a large extent the high variability in population productivity.

There were no significant correlations between Rock Ptarmigan densities and parameters of Gyrfalcon breeding performance (Table 5). Weather variables for January through April were studied in relation to Gyrfalcon breeding 
Table 5. Correlation coefficients between breeding performance of Gyrfalcons (columns), and spring Rock Ptarmigan density and seven April weather parameters (rows) in northeast Iceland 1981-2010.

\begin{tabular}{|c|c|c|c|c|}
\hline & Laying rate & Success rate & $\begin{array}{l}\text { Population } \\
\text { productivity }\end{array}$ & $\begin{array}{c}\text { Mean } \\
\text { brood size }\end{array}$ \\
\hline Rock Ptarmigan density & 0.23 & 0.23 & 0.32 & 0.18 \\
\hline Mean temperature & $0.51^{* \star}$ & 0.30 & $0.55^{\star \star}$ & $0.42^{*}$ \\
\hline Cumulative precipitation & $-0.37^{\star}$ & $-0.38^{*}$ & $-0.44^{*}$ & $-0.38^{*}$ \\
\hline Days with wind $>18 \mathrm{~m} / \mathrm{sec}$ & -0.17 & $-0.45^{*}$ & -0.29 & -0.14 \\
\hline Days with precipitation $>1 \mathrm{~mm}$ & -0.18 & -0.22 & -0.24 & -0.29 \\
\hline Days with snowfall & $-0.54^{* \star}$ & -0.36 & $-0.64^{\star \star \star}$ & $-0.54^{\star \star}$ \\
\hline Days with $100 \%$ snow cover & $-0.55^{\star \star}$ & $-0.38^{*}$ & $-0.63^{\star \star *}$ & $-0.47^{\star \star}$ \\
\hline Mean snow cover (\%) & $-0.53^{* *}$ & -0.29 & $-0.58^{* * *}$ & $-0.45^{*}$ \\
\hline
\end{tabular}

${ }^{*} \mathrm{P}=0.01-0.05 ;{ }^{*} \mathrm{P}=0.001-0.05 ;{ }^{* * *} \mathrm{P}<0.001$

performance. No relationship was found for January and February weather and breeding performance (only one of 56 correlation coefficients was significant). A better relationship was established between Gyrfalcon breeding performance and March (six of 28 coefficients significant), and especially April weather (18 of 28 coefficients significant; Table 5). The combinations of these four months, January-April, did not provide a better relation with Gyrfalcon performance than April alone, so only April weather data was used in further analysis. Important weather variables with respect to Gyrfalcon breeding performance were mean temperature, accumulated precipitation, days with snowfall, and measures of snow cover. Most of the weather variables were correlated, i.e., mean temperature and all measures of snow, also precipitation and number of days with rain $>1 \mathrm{~mm}$ or snowfall, and precipitation and number of days with wind stronger than $18 \mathrm{~m}$ per sec. Therefore, the two weather variables that were not inter-correlated, mean temperature and cumulative precipitation (for April, $\mathrm{r}=-0.121, \mathrm{P}=0.526$ ), were used in all analyses.

Both laying rate and success rate were affected by Rock Ptarmigan abundance and weather in combination (Table 6). In both cases, the two weather variables, temperature and precipita- tion, were retained in the best model, along with Rock Ptarmigan density. Mean brood size $\left(\mathrm{F}_{3,26}=3.919, \mathrm{P}=0.020\right)$, and population productivity $\left(\mathrm{F}_{3,25}=15.549, \mathrm{P}<0.001\right)$, were also affected by weather and Rock Ptarmigan abundance (Table 7). Here also, mean temperature and precipitation were retained in the model. In both models, the weather variables accounted for more of the explained variance than Rock Ptarmigan density (Table 7).

The numerical response of the Gyrfalcon population was examined further by calculating the total number of Gyrfalcons present in late summer from the sum of the total number of territorial birds (occupancy rate $\times 2$, assuming all territories were occupied by pairs) and the total number of fledglings produced (occupancy rate $\times$ population productivity). The autocorrelation function for the total number of Gyrfalcons in late summer generated a sinusoidal trajectory but none of the coefficients were significant. The partial autocorrelation function showed a significant negative coefficient with a four-year lag. The two series, Rock Ptarmigan density and total number of Gyrfalcons in late summer, did not show the same clear lag-effect as did the series for Rock Ptarmigan density and occupancy rate of Gyrfalcon territories. We saw a lag during the first cycle in the 1980s, synchrony during the 
Table 6. Logit regressions for the effects of spring Rock Ptarmigan abundance and April weather on Gyrfalcon laying rate and success rate, northeast Iceland 1981-2010.

\begin{tabular}{lcccccc}
\hline & Estimate & SE & Wald - Stat. & Lower 95\% CL & Upper 95\% CL & $\mathbf{P}$ \\
\hline Laying rate & & & & & & \\
Intercept & 0.312 & 0.185 & 2.825 & -0.052 & 0.675 & 0.093 \\
Ptarmigan density & 0.060 & 0.021 & 8.072 & 0.019 & 0.102 & 0.004 \\
April mean temp & 0.115 & 0.027 & 18.043 & 0.062 & 0.169 & 0.000 \\
April precipitation & -0.012 & 0.004 & 7.620 & -0.021 & -0.004 & 0.006 \\
Success rate & & & & & & \\
Intercept & 1.563 & 0.340 & 21.080 & 0.896 & 2.230 & 0.000 \\
Ptarmigan density & 0.116 & 0.042 & 7.692 & 0.034 & 0.198 & 0.006 \\
April mean temp & 0.128 & 0.050 & 6.497 & 0.030 & 0.226 & 0.011 \\
April precipitation & -0.018 & 0.008 & 4.998 & -0.034 & -0.002 & 0.025 \\
\hline
\end{tabular}

Table 7. Stepwise multiple regressions for the effects of spring Rock Ptarmigan abundance and April weather on Gyrfalcon mean annual brood size and population productivity, northeast Iceland 1981-2010.

\begin{tabular}{lccccc}
\hline & $\mathbf{b}$ & $\mathbf{S E}$ & $\mathbf{R}^{2}$ & $\mathbf{t}$ & $\mathbf{P}$ \\
\hline Mean brood size & & & & & \\
Intercept & 2.712 & 0.153 & & 17.691 & $<0.001$ \\
April mean temp & 0.057 & 0.024 & 0.107 & 2.416 & 0.023 \\
Ptarmigan density & 0.036 & 0.018 & 0.067 & 2.005 & 0.056 \\
April precipitation & -0.007 & 0.004 & 0.058 & -1.738 & 0.094 \\
Population productivity & & & & & \\
$\quad$ Intercept & 1.334 & 0.161 & & 8.293 & $<0.001$ \\
April mean temp & 0.116 & 0.024 & 0.276 & 4.895 & $<0.001$ \\
Ptarmigan density & 0.070 & 0.019 & 0.171 & 3.774 & 0.001 \\
April precipitation & -0.013 & 0.004 & 0.162 & -3.433 & 0.002 \\
\hline
\end{tabular}

Note: The variables are ordered by the variation explained $\left(R^{2}\right)$, calculated as the difference in $R^{2}$ with and without that variable in the complete model.

1990s, and the Gyrfalcon series leading the Rock Ptarmigan series in the 2000s (Figure 4c). The cross-correlation function for the two series showed significant coefficients for current year and one and two years back, and significant negative coefficients three to five years into the future (Figure $4 d$ ).

\section{Discussion}

In this study I have described how Gyrfalcon population parameters in Iceland relate to Rock Ptarmigan abundance. I will discuss these results both with reference to the practical aspects of studying the Gyrfalcon, and also with reference to population ecology, i.e., the 
predator-prey relationship and the possible role of the Gyrfalcon in driving cyclic changes in Ptarmigan numbers.

Gyrfalcon Population Studies.-Gyrfalcon population studies have traditionally been plagued by small sample sizes, short time series and inadequate abundance data for the main prey. These handicaps relate to the remoteness of the breeding habitat and low breeding density of Gyrfalcons. Gyrfalcons have traditional nesting territories (Poole and Bromley 1988, Nielsen and Cade 1990a, Tømmeraas 1993) that can be used for decades, centuries or even millennia (Burnham et al. 2009). Some nesting territories are occupied in most years, but others only intermittently (Nielsen and Cade 1990a). This long tenure applies to cliff-nesting Gyrfalcons, but territory tenure of tree-nesting Gyrfalcons remains to be quantified. Studies both in Iceland (Nielsen 1991) and Alaska (Booms 2010) show that adult Gyrfalcons are faithful to their territories. Until now, visiting these nesting territories and recording occupancy is the only way scientists have been able to keep track of Gyrfalcon numbers. I discuss, below, some of the problems associated with how Gyrfalcon observers have established occupancy, and also problems associated with small sample sizes, and quantification of prey numbers.

The Iceland study showed that breeding pairs of Gyrfalcons were the occupants of nesting territories for only about half the time (Table $3)$. It is harder to determine territory occupancy if Gyrfalcons are not breeding; then the decision to classify a territory as occupied is based on observations of birds and their behavior and other signs, or, as in this study, on signs alone. In this study, birds were observed on only $45 \%$ of nesting territories judged as being occupied by failed-breeders or non-breeders. Non-breeding birds can be hard to detect, and after the courtship period they may be away from the nest area for most of the day, only coming back in the evening to roost. This problem of having to judge occupancy on signs alone for a significant portion of the Gyrfalcon nesting territories in the Iceland study was probably accentuated by how late in the season I determined occupancy. Most commonly I did this in June, long after aborted courtship attempts and most breeding failures had taken place. When the observer is faced with signs only, reading them correctly and in a consistent way is important. I used roost sites with fresh mute stains, perches on the cliff with fresh mute stains, and perches and plucking locations on top of the cliff as signs of occupancy. If Gyrfalcons have gone through courtship, the signs are obvious - kills at the plucking sites; the hard thing then is to establish whether or not they laid eggs, and this can only be done by checking known nest sites. If no signs of courtship were found, I used as proof of occupancy molted down and feathers, freshly cast pellets, and fresh droppings, along with active roost sites. The best place to look for these signs (down, feathers, and pellets) was in the roost itself or on any of the frequented perches on top of the cliff. There were certain sites on the cliff, and on top of the cliff - "look-out posts" - that were only frequented by Gyrfalcons during late winter and spring (at productive territories these posts were used through summer). They were the sites that the pair, and especially the female, frequented, and this usage related to territorial activity and courtship. Fresh mute stains at these look-out posts were always a clear sign of occupancy. A confounding variable was other raptorial birds that frequented the same nesting territories as the Gyrfalcons, and left their marks behind. In my study, I only had to deal with Ravens, which were rather easy to tell apart from Gyrfalcons based on signs such as droppings, pellets, food remains, and molted feathers. For other geographic regions this may become more confusing when species like Golden Eagle (Aquila chrysaetos), Whitetailed Sea Eagle (Haliaeetus albicilla), Peregrine Falcon (Falco peregrinus), and Rough-legged Hawk (Buteo lagopus), use the same nesting territories as Gyrfalcons. 


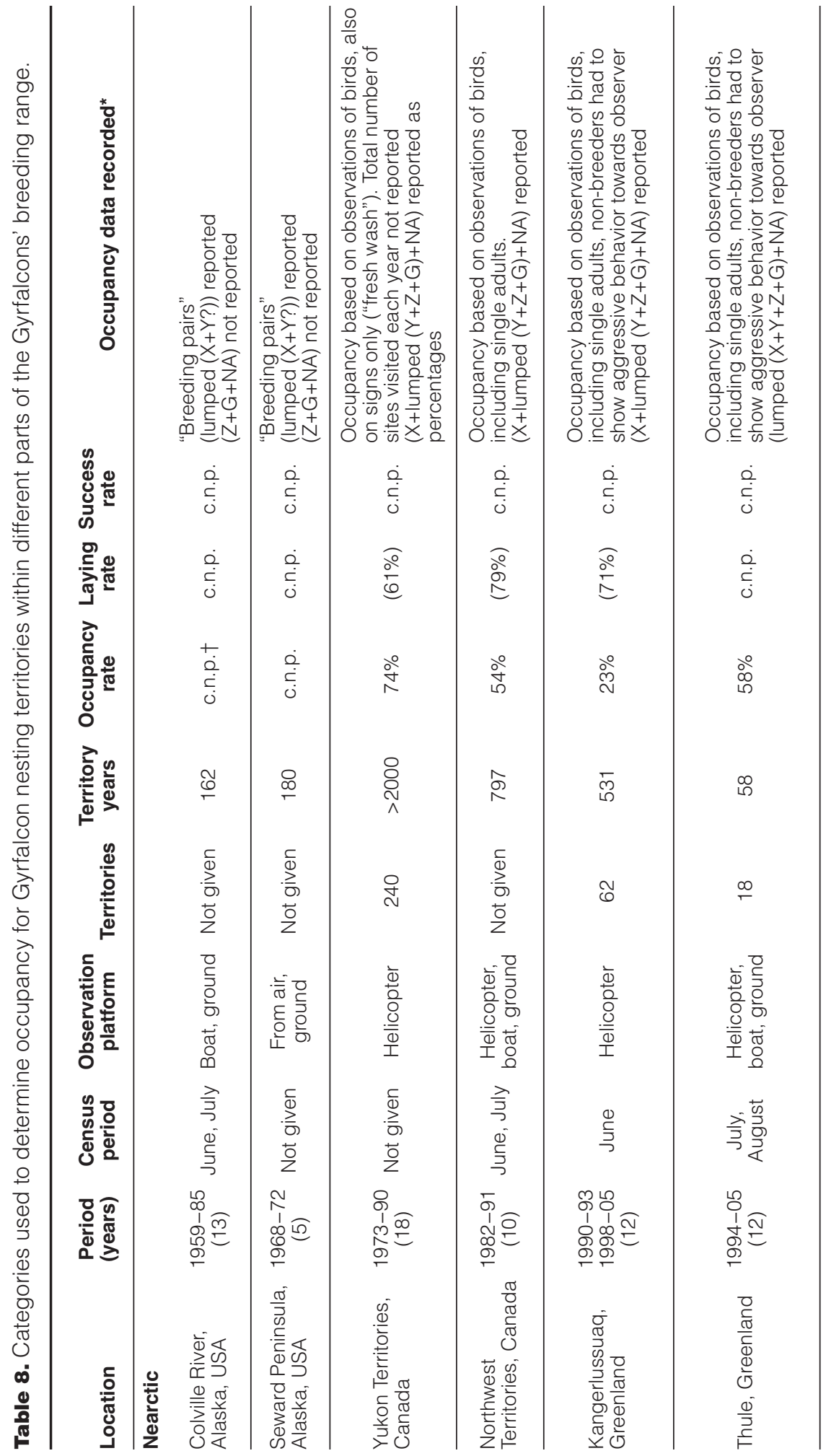




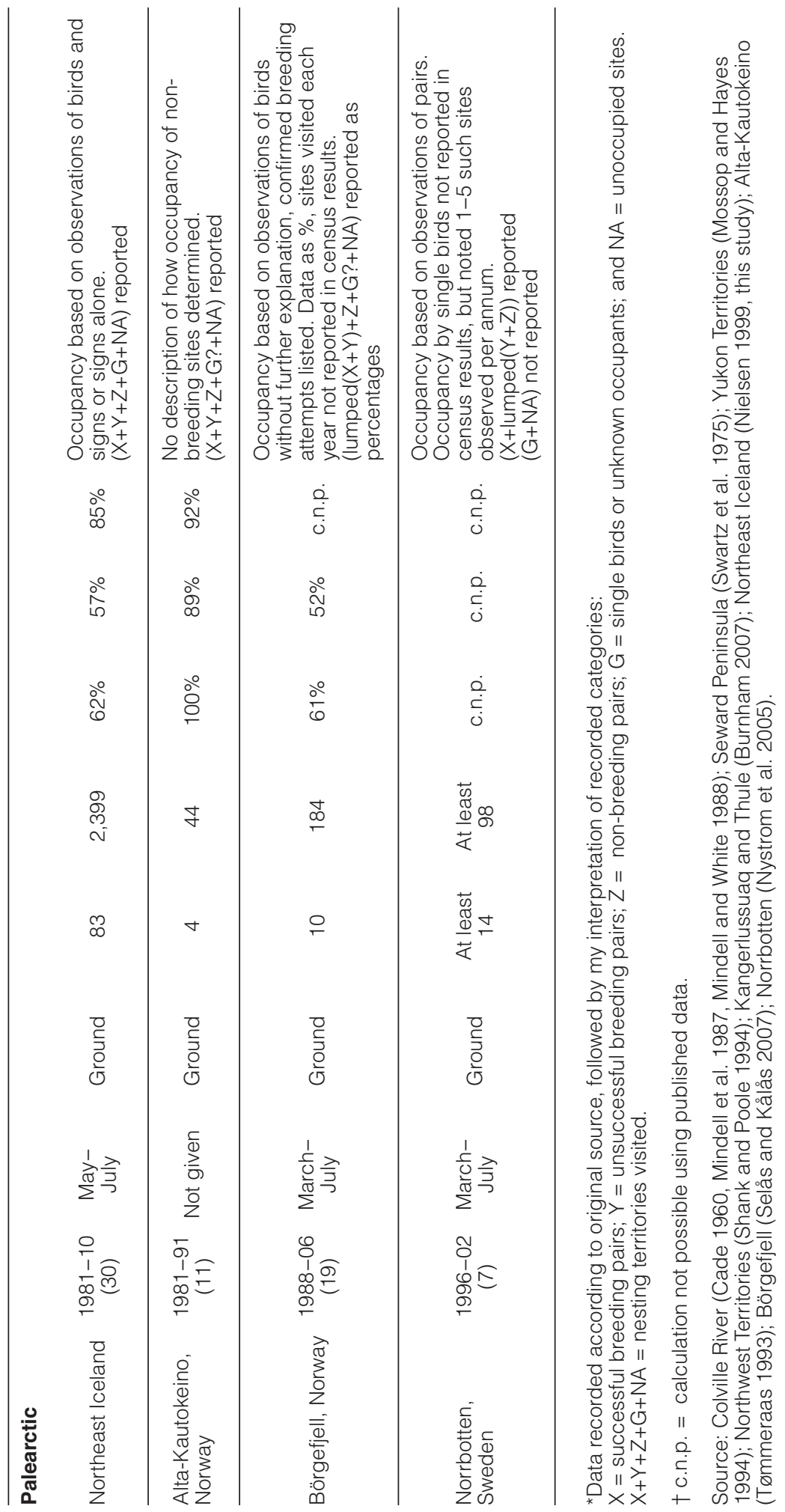


How Gyrfalcon researchers tackle the nonbreeding segment of the territorial Gyrfalcon population greatly affects the outcome of their census, and also the relationship one can expect to find with ptarmigan. From published literature I have tabulated results from 10 studies with 5-30 years of Gyrfalcon population data (Table 8). Researchers reported different categories for occupancy of territories. All studies, except the Iceland and Yukon studies, used observations of adult Gyrfalcons as the definite proof of territory occupancy. Further, there was considerable difference between studies as to what segments of the territorial population were reported. In Iceland, I assumed it to be composed of four parts: successful breeding pairs, unsuccessful breeding pairs, non-breeding pairs, and single birds or unknown occupants. In two studies, only breeding birds were counted (Colville River, Seward Peninsula), and in another study it was stated that territories with single birds were omitted when calculating occupancy (Norrbotten). Also, occupancy categories were lumped in seven studies. In three cases, territories with successful breeders and failed breeders were lumped (Colville River, Seward Peninsula, Börgefjell), and in three cases, territories with failed breeders and non-breeders were lumped (Yukon, Kangerlussuaq, Norrbotten). In the Thule study, all four occupancy categories were lumped. One possible explanation for this tendency to lump categories, i.e., failed breeders and other occupants, was the observation platform. Observations from a helicopter or fixed-wing aircraft makes closely detailed search for signs, such as shed down and feathers, pellets, fresh droppings, and food remains, difficult or impossible. Timing of the census is another important factor. Late visits should bias results both with respect to occupancy rate (underestimates the rate), and composition of occupancy (overestimates successful breeders). Booms et al. (2010) suggested a solution to this problem by repeated visits to territories to calculate detection probability estimates so as to derive unbiased measures of occupancy rate. My study shows that the relation one can expect to find between the Gyrfalcon and ptarmigan depends on what components of the Gyrfalcon population we record. I only found a time-lag between occupancy rate of Gyrfalcon territories and Rock Ptarmigan population numbers when I used the occupancy rate derived from the sum of all four variables of the Gyrfalcon population (Figure 4).

Another obvious problem was sample size, and also how territories for monitoring are selected. Gyrfalcon nesting territories were not occupied at random, some were preferred and used almost all years, while others were only used intermittently (Nielsen and Cade 1990a). Four of the studies cited in Table 8 had small annual sample sizes (4-18 territories), which in itself was a problem with regard to all calculations and comparisons. Further, when not all territories on a study area were visited to determine occupancy, there was the danger of selecting "good" territories for monitoring, territories that are nearly always occupied regardless of Gyrfalcon numbers.

Any study addressing population ecology of Gyrfalcons should also include density estimates of the main prey. I found six studies in the published literature, including the present one, where indices of ptarmigan numbers were used to interpret Gyrfalcon population dynamics (Table 9). The methods used to enumerate the ptarmigan have been varied. Three studies used plot counts to estimate ptarmigan density. One study used incidental observations of ptarmigan collected during other field work. Two studies used indirect indices of abundance, namely pellet counts and ptarmigan wing collections.

I caution against using indirect indices with unknown relation to ptarmigan numbers, and discuss the two cases further. Ptarmigan wings were collected from hunters, not to get a population size index, but to derive age ratios for the population (Framstad 2004). The sample could not be standardized with respect to effort, and it was not known how it related to 
Table 9. Methods used to derive population indices for Rock Ptarmigan and Willow Ptarmigan in Gyrfalcon studies within different parts of the Gyrfalcons' range.

\begin{tabular}{|c|c|c|c|c|c|}
\hline Location & Species* & $\begin{array}{l}\text { Period } \\
\text { (years) }\end{array}$ & Methods & $\begin{array}{l}\text { Prey index } \\
\text { relates to }\end{array}$ & $\begin{array}{l}\text { Prey index used in } \\
\text { Gyrfalcon study }\end{array}$ \\
\hline \multicolumn{6}{|l|}{ Nearctic } \\
\hline $\begin{array}{l}\text { Yukon Territories, } \\
\text { Canada }\end{array}$ & WP & $\begin{array}{l}1975-90 \\
(16)\end{array}$ & Plot counts & Spring & Numerical response \\
\hline $\begin{array}{l}\text { Northwest } \\
\text { Territories, } \\
\text { Canada }\end{array}$ & $\mathrm{RP}$ & $\begin{array}{l}1983-91 \\
(9)\end{array}$ & $\begin{array}{l}\text { Plot counts, on foot } \\
\text { or from a helicopter }\end{array}$ & Spring & Numerical response \\
\hline \multicolumn{6}{|l|}{ Palearctic } \\
\hline Northeast Iceland & $\mathrm{RP}$ & $\begin{array}{l}1981-10 \\
(30)\end{array}$ & Plot counts, on foot & Spring & $\begin{array}{l}\text { Numerical and } \\
\text { functional response }\end{array}$ \\
\hline $\begin{array}{l}\text { Alta-Kautokeino, } \\
\text { Norway }\end{array}$ & LP & $\begin{array}{l}1982-91 \\
(10)\end{array}$ & $\begin{array}{l}\text { Incidental observations } \\
\text { during other field work }\end{array}$ & Spring and summer & Numerical response \\
\hline $\begin{array}{l}\text { Börgefjell, } \\
\text { Norway }\end{array}$ & LP & $\begin{array}{l}1987-05 \\
(19)\end{array}$ & $\begin{array}{l}\text { Wings collected from } \\
\text { hunters }\end{array}$ & $\begin{array}{l}\text { Autumn and early } \\
\text { winter }\end{array}$ & Numerical response \\
\hline $\begin{array}{l}\text { Norrbotten, } \\
\text { Sweden }\end{array}$ & LP & $\begin{array}{l}1996-00 \\
(5)\end{array}$ & Pellet counts on transects & $\begin{array}{l}\text { Most probably } \\
\text { spring and previous } \\
\text { winter, and fall }\end{array}$ & $\begin{array}{l}\text { Numerical and } \\
\text { functional response }\end{array}$ \\
\hline
\end{tabular}

*WP = Willow Ptarmigan; RP = Rock Ptarmigan; LP = lumped Rock and Willow Ptarmigan.

Source: Yukon Territories (Mossop and Hayes 1994); Northwest Territories (Poole and Bromley 1988, Shank and Poole 1994); northeast Iceland (Nielsen 1999, this study); Alta-Kautokeino (Tømmeraas 1993, and pers. comm.); Börgefjell (Selås and Kelås 2007); Norrbotten (Nystrom et al. 2005).

the number of ptarmigan hunted, let alone ptarmigan population size. Also, in Scandinavia the relationship between bag size and population size of Willow Ptarmigan was not linear (Willebrand et al. 2011). I have a large collection of Rock Ptarmigan wings from hunters in northeast Iceland (1995-2002 and $1995-2010, \mathrm{n}=19,239)$ but found no significant relationship between the number of wings acquired and the spring population index of Rock Ptarmigan in year $\mathrm{t}(\mathrm{r}=0.210, \mathrm{P}=$ $0.471)$, or year $t+1(r=0.280, P=0.355$; unpubl. data). One of the problems with using ptarmigan pellet counts was interpreting for what season the collections described density. On the one hand, if the counts were done after spring thaw, they could give an integrated view of relative density from fall to spring. On the other hand, if pellet counts were done before spring melt, they should, depending on last snow or advancement of melt, give a more instantaneous picture of relative density. Unfortunately, the timing was not stated in the paper (Nystrom et al. 2005). Another problem with pellets is how they were deposited. Piles with dozens of pellets are found where the birds have roosted during the night. At daytime rest sites, pellets also pile up but to a lesser extent. When the birds are active-walking, flying, foraging - they defecate at regular intervals. The observer in the field is faced with huge piles, small piles, and single droppings scattered all over, and the detection probability depends on pile size. The problem with evaluating such data is obvious: how do you treat piles versus single droppings; how do you correct for detectability? Further, in both of these studies it was not possible to tease apart the two species of ptarmigan, Rock Ptarmigan and Willow Ptarmigan. Gyrfalcons did not 
necessarily prey indiscriminately on the two species of ptarmigan where they were sympatric with the Gyrfalcon (Nystrom et al. 2006), and also the dynamics of the two ptarmigan species need not be in synchrony on a local scale (Maria Hörnell-Willebrand pers. comm.).

The problem with designating to which season the prey index related also has bearing on other studies (Table 9). Gyrfalcon counts always represented occupied nesting territories in spring, and breeding success of occupants, their food, etc. Preferably, we would want to have a prey population index that relates to these same periods, i.e., late winter and spring (courtship period into the nestling period). Three of the ptarmigan counts related to spring, one related to spring and summer, one to fall to mid-winter, and one probably to fall through the following spring (Table 9). Considering both high and greatly varying mortality rates of ptarmigan during fall, winter, and spring (Gardarsson 1988, Watson and Moss 2008), then how much relation can one expect between Gyrfalcon laying rate, success rate and brood size, and the number of ptarmigan either five to seven months back in time, or three to four months into the future? The Iceland study showed that Gyrfalcons were responding to weather measured in March and April, i.e., during courtship, egg laying and early incubation. This should not come as a surprise considering the breeding biology of the species, i.e. cessation of hunting by the female at the start of courtship two to four weeks prior to egg laying (Platt 1989, Nielsen and Cade 1990a), and subsequent build up of body reserves (Newton et al. 1983, Nielsen 1991). Accordingly, the most parsimonious way to look for a connection between food condition and Gyrfalcon breeding parameters would be to use an index describing ptarmigan abundance at the end of winter and in spring. Ptarmigan are easy to count, and I encourage Gyrfalcon researchers to use quantitative indices of abundance in spring for their studies.
To derive the functional response of the Gyrfalcon, one must have information on food composition. The easiest way to study food habits is to collect prey remains in the nesting territory. Both Nielsen (1999) and Booms and Fuller (2003) have discussed possible biases inherent in such an approach. Also, as stated above in Methods, for samples to be comparable, they should relate to the whole nesting period, and prey remains must be collected both in the nest itself and at other places where remains accumulate, because prey composition changes as the season progresses. The early part of the season is dominated by ptarmigan, while other prey items increase in the latter half of the breeding season to varying degrees, depending on the abundance of ptarmigan.

\section{Gyrfalcon and Rock Ptarmigan Dynamics.-} The possible role of predators in generating regular cycles of numbers in hares and microtine rodents has been much studied (Keith 1963, Krebs and Myers 1974, Finerty 1980, Norrdahl 1995, Korpimäki and Krebs 1996). The effects of the different predators vary, and depend on such factors as prey choice (generalist versus specialist predator), the functional response, movement pattern (resident, migratory, nomadic), the numerical response (no response, or track prey with or without timelags), and whether their density is limited by prey numbers (Andersson and Erlinge 1977, Ydenberg 1987, Korpimäki and Norrdahl 1989, Hanski et al. 1991, Rohner 1995). Predators capable of driving cycles should be specialized on the cyclic prey in their food choice at all times, they should be resident, their density limited by prey numbers, and show a typetwo functional response and a numerical response with a time-lag that amounts to $1 / 4$ of the cycle length. This is the "resident specialist predator," one of the prerequisites of a coupled predator-prey cycle (Andersson and Erlinge 1977). The cyclic hares and microtine rodents are the dominant vertebrate herbivores within their ecosystems (Angelstam et al. 1985, Boutin et al. 1995). The changes in their numbers, and the numbers of their associated pred- 
ators, affect populations of alternative prey groups (the alternative prey hypothesis). The populations of alternative prey are forced, through predation by the small mammal predators, to track the cyclic populations of the dominant herbivores (Siivonen 1948, Hagen 1952b, Marcström et al. 1988, Marcström et al. 1989). Ptarmigan belong to these alternative prey groups and, in Fennoscandia and boreal North America, are thought to track respectively the microtine rodent cycle (Hagen 1952b, Steen et al. 1988) and Snowshoe Hare (Lepus americanus) cycle (Boutin et al. 1995).

How does the Gyrfalcon fit into the role of the resident specialist predator? - My study in Iceland showed the Gyrfalcon was resident with only local movements of mainly juveniles (Nielsen and Cade 1990a). The movement pattern was such that Rock Ptarmigan populations that breed in areas where there were no nesting Gyrfalcons (i.e., south-west Iceland) were subject to Gyrfalcon predation from fall through spring. In essence, the Gyrfalcon was sympatric with the Rock Ptarmigan in all seasons. The food habits of Gyrfalcons in Iceland were specialized, and Rock Ptarmigan was the main food in all seasons and all years (Nielsen and Cade 1990b, Nielsen 2003). The Gyrfalcons' functional response showed high reliance on Rock Ptarmigan at all observed ptarmigan densities. It was only at the lowest ptarmigan densities that I saw some reduction in consumption rate, indicating a convex trajectory. The numerical response showed a timelag; with respect to occupied territories, the time-lag was three to four years, and with respect to combined adult and fledgling numbers, the time-lag was zero to two years. Irregularities with respect to Rock Ptarmigan numbers and the combined number of Gyrfalcons (adults + fledglings) were caused by the effect of weather on reproduction. The Gyrfalcons produced in all years, and this study showed that weather had a great effect on population productivity, and weather factors explained much more of the variation $\left(\mathrm{R}^{2}=\right.$ $0.438)$ than spring Rock Ptarmigan density $\left(R^{2}\right.$
$=0.171)$ (Table 7). According to this finding then, depending on spring weather, large Gyrfalcon cohorts can be produced in both good and bad Rock Ptarmigan years.

Another fact that suggests a connection between cyclic changes of the Rock Ptarmigan population and Gyrfalcon abundance was the relation between falcon numbers and Rock Ptarmigan mortality rates. A population model for Rock Ptarmigan in Iceland included two lag factors (Magnússon et al. 2004). One factor, termed additive juvenile mortality, described mortality suffered by juveniles in excess of adult mortality during autumn and winter. This mortality rate, as measured on my study area, showed a three year time-lag with respect to changes in Rock Ptarmigan numbers, and it was significantly correlated with the total number of Gyrfalcons at the end of the breeding season (adults + fledglings).

As I have stated before (Nielsen 1999: p. 1045), I find it hard to conceive that the Gyrfalcon population on my study area was limited by anything other than food. It was the interaction of food-mediated effects on adult Gyrfalcon survival and juvenile recruitment into the breeding population that created the observed time-lag between Gyrfalcons and Rock Ptarmigan. My conclusion regarding the Gyrfalcon in Iceland is that it fits the role of the resident specialist predator (Table 10), and the Gyrfalcon-Rock Ptarmigan system in Iceland could represent a coupled predator-prey cycle. In Iceland, the Rock Ptarmigan is the dominant wild vertebrate herbivore and has a central position within the food web, a role played by microtine rodents and hares in other ecosystems. So the "alternative prey hypothesis" does not apply to the population change of the Rock Ptarmigan in Iceland.

What is the nature of the Gyrfalcon-ptarmigan relationship in other areas, and are there indications of coupled Gyrfalcon-ptarmigan cycles from elsewhere? - All of the tabulated populations can be considered to be ptarmigan 
Table 10. Observed characteristics of Gyrfalcon populations in areas where the relationship between the falcon and its ptarmigan prey has been studied.

\begin{tabular}{|c|c|c|c|c|c|}
\hline Site & $\begin{array}{l}\text { Ptarmigan } \\
\text { specialist }\end{array}$ & Residency & $\begin{array}{l}\text { Functional } \\
\text { response }\end{array}$ & $\begin{array}{l}\text { Numerical response } \\
\text { (territories occupied) }\end{array}$ & $\begin{array}{c}\text { Numerical response } \\
\text { (population } \\
\text { productivity) }\end{array}$ \\
\hline \multicolumn{6}{|l|}{ Nearctic } \\
\hline $\begin{array}{l}\text { Yukon Territories, } \\
\text { Canada }\end{array}$ & yes & $\begin{array}{l}\text { Juveniles } \\
\text { migratory, adults? }\end{array}$ & Not described & Time-lag 0-1 year & No relation \\
\hline $\begin{array}{l}\text { Northwest Territories, } \\
\text { Canada }\end{array}$ & yes & Migratory & Not described & No relation & No relation \\
\hline \multicolumn{6}{|l|}{ Palearctic } \\
\hline Northeast Iceland & yes & $\begin{array}{l}\text { Resident, local } \\
\text { dispersal of } \\
\text { juveniles }\end{array}$ & Convex & Time-lag 3-4 years & $\begin{array}{l}\text { Determined by Rock } \\
\text { Ptarmigan number and } \\
\text { spring weather }\end{array}$ \\
\hline $\begin{array}{l}\text { Alta-Kautokeino, } \\
\text { Norway }\end{array}$ & yes & $\begin{array}{l}\text { Juveniles } \\
\text { migratory, adults? }\end{array}$ & Not described & No relation & No relation \\
\hline Börgefjell, Norway & yes & $\begin{array}{l}\text { Juveniles } \\
\text { migratory, adults? }\end{array}$ & Not described & No relation & Not examined \\
\hline Norrbotten, Sweden & yes & $\begin{array}{l}\text { Juveniles } \\
\text { migratory, adults? }\end{array}$ & Convex & No relation & $\begin{array}{l}\text { Determined by } \\
\text { ptarmigan numbers }\end{array}$ \\
\hline
\end{tabular}

Source: Northeast Iceland (Nielsen 1999, this study); Yukon Territories (Mossop and Hayes 1994), Northwest Territories (Poole and Boag 1988; Shank and Poole 1994); Alta-Kautokeino (Tømmeraas 1993); Börgefjell (Selås and Kålås 2007); Norrbotten (Nystrom et al. 2005)

specialists (Table 10). Only the Gyrfalcon population in Iceland was fully residential. Of the others, one population was migratory, and at least the juveniles were migratory among the rest. The Gyrfalcons' functional response was described for only one of those populations and was similar to the situation in Iceland, with high per capita consumption of ptarmigan at all observed ptarmigan densities. Apart from the Iceland study, only the Yukon study showed a numerical response by the Gyrfalcon population (occupancy rate) to changes in ptarmigan density. The cross-correlation function of the Yukon data showed that a high occupancy rate of Gyrfalcon territories was associated with high Willow Ptarmigan densities the same year and one year previously, and low densities three to five years into the future. This differed somewhat from the results in Iceland, where high occupancy rate of Gyrfalcon territories was associated with high Rock Ptarmigan densities two to five years previously, and low densities two to five years into the future (Figure $4 b$ ). Among the other studies, there was no relation between occupancy rate of Gyrfalcon territories and ptarmigan numbers. The numerical response by Gyrfalcons, measured as population productivity, showed a relation with ptarmigan numbers only in Norrbotten, Sweden and in Iceland (Table 10). In Iceland, weather also emerged as an important determinant of population productivity of Gyrfalcons. An obvious problem with all these time series describing Gyrfalcon-ptarmigan relationships was how short the series were. As a rule of thumb, series should at least be three times the cycle period to be useful for time series analysis. Only the Iceland series approached this minimum length.

All these results (Tables 8-10) pertaining to the Gyrfalcon-ptarmigan relationship demonstrate 
the need for long-term monitoring to describe this interesting system. Such projects should include large samples of nesting territories studied over many years, and also include accurate monitoring of ptarmigan abundance.

\section{Conclusions}

The Gyrfalcon in Iceland is a resident specialist predator, and the functional and numerical responses suggest that the predator-prey relationship of the Gyrfalcon and the Rock Ptarmigan is a coupled predator-prey cycle. Time series from other parts of the Gyrfalcons' range, except perhaps the Yukon Territories, suggest otherwise. The results emphasize the need for long-term monitoring of Gyrfalcon and ptarmigan population parameters to understand the relationship between predator and prey. Further, to understand the population process indicated by the monitoring, we need studies on the demographics of the Gyrfalcon, on dispersal, and on the non-territorial segment of the population. Recently Booms (2010) has shown for the Gyrfalcon the applicability of genetic methods for addressing questions relating to the demographics of the territorial population, and both natal and breeding dispersal. Perhaps this technology could be used further afield, away from territories, using cast pellets, feathers, or droppings, to study population size and composition (Mowat and Strobeck 2000).

\section{ACKNOWLEDGMENTS}

Financial support for 1981-1993 was received from the National Geographic Society, the Icelandic Science Fund, The Peregrine Fund, Inc., the Andrew Mellon Foundation, the E. Alexander Bergstrom Memorial Research Fund, and the Arctic Institute of North America. For 1986 and 1994-2010, this research was funded by the Icelandic Institute of Natural History. The Lake Mývatn Research Station provided field facilities. Field assistance was provided by J.Ó. Hilmarsson, G. Phráinsson, I. Petersen, H. Bárðarson, Ó. Einarsson, E.Ó. Porleifsson,
Ó.H. Nielsen, A.Ö. SnæPórsson, P.P. Björnsson, S. Nielsen. Many more people have helped in various ways with the field studies. These studies started out as a Ph.D. project at Cornell University, Ithaca, New York, under the supervision of Professor Tom J. Cade.

\section{Literature Cited}

ANDERsson, M., AND S. ERLINGE. 1977. Influence of predation on rodent populations. Oikos 29:591-597.

AnDREEV, A. 1988. The 10 year cycle of the Willow Grouse of Lower Kolyma. Oecologia 76:261-267.

Andrén, H., P. Angelstam, E. Lindström, AND P. WIDÉN. 1985. Differences in predation pressure in relation to habitat fragmentation: An experiment. Oikos 45:273-277.

Angelstam, P., E. Lindström, AND P. WidÉN. 1985. Synchronous short-term population fluctuations of some birds and mammals in Fennoscandia-occurrence and distribution. Holarctic Ecology 8:285-298.

Bergerud, A. T. 1970. Population dynamics of the Willow Ptarmigan Lagopus lagopus alleni L. in Newfoundland 1955 to 1965. Oikos 21:299-325.

Bergerud, A. T. 1988. Population ecology of North American grouse. Pages 578-648 in A. T. Bergerud and M. W. Gratson (Eds.). Adaptive Strategies and Population Ecology of Northern Grouse. University of Minnesota Press, Minneapolis, Minnesota, USA.

BERRYMAN, A. A. 1996. What causes population cycles of forest Lepidoptera? Trends in Ecology \& Evolution 11:28-32.

Berryman, A. A. 2002. Population Cycles: The Case for Trophic Interactions. Oxford University Press, Oxford, UK.

Booms, T. L. 2010. Gyrfalcon breeding biology. Ph.D. dissertation, University of Alaska, Fairbanks, Alaska, USA.

Booms, T. L., T. J. CAde, AND N. J. Clum. 2008. Gyrfalcon (Falco rusticolus). In A. Poole (Ed.). The Birds of North America Online. Cornell Laboratory of Ornithology, 
Ithaca, New York, USA. Retrieved from The Birds of North America Online database: http://bna.birds.cornell.edu/bna/ species/114

Booms, T. L., AND M. R. FulLeR. 2003. Gyrfalcon feeding behavior during the nestling period in central West Greenland. Arctic 56:341-348.

Booms, T. L., P. F. SCHEMPF, B. J. MCCAFFERY, M. S. LiNDBERG, AND M. R. FULLER. 2010. Detection probability of cliff-nesting raptors during helicopter and fixed-wing aircraft surveys in western Alaska. Journal of Raptor Research 44:175-187.

Boutin, S., C. J. Krebs, R. Boonstra, M. R. T. Dale, S. J. Hannon, K. Martin, A. R. E. Sinclair, J. N. M. SMith, R. TuRKINGTON, M. Blower, A. Byrom, F. I. Doyle, C. Doyle, D. Hik, L. Hofer, A. Hubbs, T. Karels, D. L. Murray, V. Nams, M. O'Donoghue, C. RoHner, AND S. SCHWEIGER. 1995. Population changes of the vertebrate community during a Snowshoe Hare cycle in Canada's boreal forest. Oikos 74:69-80.

BRYANT, J. P. 1981a. Phytochemical deterrence of Snowshoe Hare browsing by adventitious shoots of four Alaskan trees. Science 213:889-890.

BRYANT, J. P. 1981b. The regulation of Snowshoe Hare feeding behaviour during winter by plant antiherbivore chemistry. Pages 720-731 in K. Myers and C. D. MacInnes (Eds.). Proceedings of the World Lagomorph Conference, University of Guelph, Ontario, Canada.

Bryant, J. P., AND P. J. KuROPAT. 1980. Selection of winter forage by sub-arctic browsing vertebrates: The role of plant chemistry. Annual Review of Ecology and Systematics 11:261-285.

BURNHAM, K. K. 2007. Inter- and intraspecific variation of breeding biology, movements, and genotype in Peregrine Falcon Falco peregrinus and Gyrfalcon F. rusticolus populations in Greenland. Ph.D. dissertation, University of Oxford, Oxford, UK.
Burnham, K. K., W. A. Burnham, AND I. NEWTON. 2009. Gyrfalcon Falco rusticolus post-glacial colonization and extreme longterm use of nest-sites in Greenland. Ibis 151:514-522.

CADE, T. J. 1960. Ecology of the Peregrine and Gyrfalcon populations in Alaska. University of California Publications in Zoölogy 63:151-290.

CAde, T. J., P. KosKimies, AND Ó. K. NiELSEN. 1998. Falco rusticolus Gyrfalcon. Birds of the Western Palearctic Update 2:1-25.

Chatfield, C. 1989. The Analysis of Time Series: An Introduction, $4^{\text {th }}$ ed. Chapman $\&$ Hall, London, UK.

Cramp, S., AND K. E. L. Simmons. 1980. The Birds of the Western Palearctic, vol. 2. Oxford University Press, Oxford, UK.

EINARSSON, M. Á. 1979. Climatic conditions of the Lake Mývatn area. Oikos 32:29-37.

Elton, C. C. 1924. Periodic fluctuations in the numbers of animals: Their causes and effects. British Journal of Experimental Biology 2:119-163.

EythorSSON, J., AND H. SigTRYGGSSON. 1971. The climate and weather of Iceland. The Zoology of Iceland, vol. 1, part 3. Munksgaard, Copenhagen, Denmark.

FINERTY, J. P. 1980. The population ecology of cycles in small mammals: Mathematical theory and biological fact. Yale University Press, New Haven, Connecticut, USA.

FrAMSTAD, E. 2004. Monitoring programme for terrestrial ecosystems. Ground vegetation, epiphytes, small rodents and birds at the monitoring sites, 2003. NINA Oppdragsmelding 839 (In Norwegian, with English abstract).

GARDARSSON, A. 1988. Cyclic population changes and some related events in Rock Ptarmigan in Iceland. Pages 300-329 in A. T. Bergerud and M. W. Gratson (Eds.). Adaptive Strategies and Population Ecology of Northern Grouse. University of Minnesota Press, Minneapolis, Minnesota, USA.

Hagen, Y. 1952a. The Gyr-falcon (Falco $r$. rusticolus L. ) in Dovre, Norway. Skrifter 
utgitt av Det Norske Videnskaps-Akademi i Oslo. I. Matematisk-Naturvidenskapelige Klasse. 4:1-37.

HAGEN, Y. 1952b. Rovfuglene og Viltpleien. Gyldendal Norsk forlag, Oslo (in Norwegian).

Hanski, I., L. Hansson, And H. HentTonen. 1991. Specialist predators, generalist predators, and the microtine rodent cycle. Journal of Animal Ecology 60:353-367.

HANSKI, I., P. TURCHIN, E. KoRPIMÄKI, AND H. HentTONEN. 1993. Population oscillations of boreal rodents: Regulation by mustelid predators leads to chaos. Nature 364:232235.

HiLl, T., AND P. LeWICKI. 2006. Statistics, Methods and Applications. StatSoft, Tulsa, Oklahoma, USA.

Holling, C. S. 1959. Some characteristics of simple types of predation and parasitism. Canadian Entomologist 91:385-398.

Holmstad, P. R., P. J. Hudson, AND A. SkorPING. 2005a. The influence of a parasite community on the dynamics of a host population: A longitudinal study on Willow Ptarmigan and their parasites. Oikos 111:377-391.

Holmstad, P. R., P. J. Hudson, V. VAndviK, AND A. SKORPING. 2005b. Can parasites synchronise the population fluctuations of sympatric tetraonids? - Examining some minimum conditions. Oikos 109:429-434.

Hudson, P. J., A. P. Dobson, And D. NewBORN. 1998. Prevention of population cycles by parasite removal. Science 282:2256-2258.

Keith, L. B. 1963. Wildlife's Ten-year Cycle. University of Wisconsin Press, Madison, Wisconsin, USA.

KorPIMÄKI, E., AND C. J. KREBS. 1996. Predation and population cycles of small mammals $-\mathrm{A}$ reassessment of the predation hypothesis. BioScience 46:754-764.

KorPIMÄKI, E., AND K. NORRDAHL. 1989. Predation of Tengmalm's Owls: Numerical responses, functional responses and dampening impact on population fluctuations of microtines. Oikos 54:154-164.
Krebs, C. J., S. Boutin, R. Boonstra, A. R. E. Sinclair, J. N. M. Smith, M. R. T. Dale, K. Martin, and R. Turkington. 1995. Impact of food and predation on the Snowshoe Hare cycle. Science 269:11121115.

Krebs, C. J., AND J. H. Myers. 1974. Population cycles in small mammals. Advances in Ecological Research 8:267-399.

LANGVATN, R. 1977. Characteristics and relative occurrence of remnants of prey found at nesting places of Gyrfalcon Falco rusticolus. Ornis Scandinavica 8:113-125.

Liengme, B. V. 2000. A Guide to Microsoft Excel for Scientists and Engineers, $2^{\text {nd }}$ ed. Butterworth-Heinemann, Oxford, UK.

LINDBERG, P. 1983. Relations between the diet of Fennoscandian Peregrines Falco peregrinus and organochlorines and mercury in their eggs and feathers, with comparison to the Gyrfalcon Falco rusticolus. Ph.D. dissertation, University of Göteborg, Göteborg, Sweden.

MAgnÚSSON, K., J. BRYNJARSDÓtTIR, AND Ó. K. Nielsen. 2004. Population cycles in Rock Ptarmigan Lagopus muta: Modelling and parameter estimation. Technical report RH-19-2004, Science Institute, University of Iceland, Reykjavík, Iceland.

Marcström, V., L. B. KeIth, E. Engren, AND J. R. CARY. 1989. Demographic responses of Arctic Hares (Lepus timidus) to experimental reductions of Red Foxes (Vulpes vulpes) and Martens (Martes martes). Canadian Journal of Zoology 67:658-668.

Marcström, V., R. E. Kenward, and E. ENGREN. 1988. The impact of predation on boreal tetraonids during vole cycles: An experimental study. Journal of Animal Ecology 57:859-872.

McIntyre, C. L., and L. G. Adams. 1999. Reproductive characteristics of migratory Golden Eagles in Denali National Park, Alaska. Condor 101:115-123.

Mindell, D. P., J. L. B. Albuquerque, And C. M. White. 1987. Breeding population fluctuations in some raptors. Oecologia 72:382-388. 
Mindell, D. P., AND C. M. White. 1988. Fluctuations of observed breeding Roughlegged Hawks and Gyrfalcons: regularity reconsidered. Oecologia 77:14-18.

Mossop, D., AND R. HAYES. 1994. Long term trends in the breeding density and productivity of Gyrfalcon Falco rusticolus in the Yukon Territory, Canada. Pages 403-413 in B. -U. Meyburg and R. D. Chancellor (Eds.). Raptor Conservation Today. Helm Information Inc., Mountfield, East Sussex, UK.

Mowat, G., AND C. Strobeck. 2000. Estimating population size of Grizzly Bears using hair capture, DNA profiling, and markrecapture analysis. The Journal of Wildlife Management 64:183-193.

Myrberget, S. 1984. Population cycles of Willow Grouse Lagopus lagopus on an island in northern Norway. Fauna Norvegica Series C, Cinclus 7:46-56.

Newton, I. 1979. Population Ecology of Raptors. Buteo Books, Vermillion, South Dakota, USA.

NeWTON, I., AND M. MARQUiss. 1982a. Fidelity to breeding area and mate in Sparrowhawks Accipiter nisus. Journal of Animal Ecology 51:327-341.

Newton, I., AND M. MARQuiss. 1982b. Food, predation and breeding season in Sparrowhawks (Accipiter nisus). Journal of Zoology 197:221-240.

Newton, I., M. Marquiss, and A. Village. 1983. Weights, breeding, and survival in European Sparrowhawks. Auk 100:344354.

NiElsen, Ó. K. 1986. Population ecology of the Gyrfalcon in Iceland with comparative notes on the Merlin and the Raven. Ph.D. dissertation, Cornell University, Ithaca, New York, USA.

NIELSEN, Ó. K. 1991. Age of first breeding and site fidelity of Gyrfalcons. Náttúrufræðingurinn 60:135-143 (In Icelandic with English summary).

NIELSEN, Ó. K. 1993. Initiation of territoriality among Icelandic Rock Ptarmigan in spring.
Náttúrufræðingurinn 63:29-37 (In Icelandic with English summary).

Nielsen, Ó. K. 1996. Rock Ptarmigan censuses in northeast Iceland. Náttúrufræðingurinn 65:137-151 (In Icelandic with English summary).

NiELSEN, Ó. K. 1999. Gyrfalcon predation on ptarmigan: Numerical and functional responses. Journal of Animal Ecology 68:1034-1050.

NIELSEN, Ó. K. 2003. The impact of food availability on Gyrfalcon (Falco rusticolus) diet and timing of breeding. Pages 283-302 in D. B. A. Thompson, S. M. Redpath, A. H. Fielding, M. Marquiss, and C. A. Galbraith (Eds.). Birds of Prey in a Changing Environment. Scottish Natural Heritage, Edinburgh, UK.

NiElsEn, Ó. K., AND T. J. CADE. 1990a. Annual cycle of the Gyrfalcon in Iceland. National Geographic Research 6:41-62.

Nielsen, Ó. K., AND T. J. Cade. 1990b. Seasonal changes in food habits of Gyrfalcons in NE-Iceland. Ornis Scandinavica 21:202211.

Nielsen, Ó. K., ANd G. Pétursson. 1995. Population fluctuations of Gyrfalcon and Rock Ptarmigan: Analysis of export figures from Iceland. Wildlife Biology 1:65-71.

NORRDAHL, K. 1995. Population cycles in northern small mammals. Biological Reviews 70:621-637.

Nyström, J., L. Dalen, P. Hellström, J. Ekenstedt, H. ANGLEby, AND A. ANGerbJÖRN. 2006. Effect of local prey availability on Gyrfalcon diet: DNA analysis on ptarmigan remains at nest sites. Journal of Zoology 269:57-64.

NySTROM, J., J. EKENSTEDT, J. ENGSTROM, AND A. AngerbJorn. 2005. Gyr Falcons, ptarmigan and microtine rodents in northern Sweden. Ibis 147:587-597.

Palmer, R. S. 1988. Handbook of North American Birds. Yale University Press, New Haven, Connecticut, USA and London, UK.

PlatT, J. B. 1976. Gyrfalcon nest site selection and winter activity in the western Canadian 
Arctic. Canadian Field-Naturalist 90:338345.

Platt, J. B. 1989. Gyrfalcon courtship and early breeding behavior on the Yukon north slope. Sociobiology 15:43-69.

Poole, K. G., AND R. G. BRomley. 1988. Natural history of the Gyrfalcon in the central Canadian Arctic. Arctic 41:31-38.

Potapov, E., And R. SAle. 2005. The Gyrfalcon. T. \& A. D. Poyser, London, UK.

RoHNER, C. 1995. Great Horned Owls and Snowshoe Hares: What causes the time lag in the numerical response of predators to cyclic prey. Oikos 74:61-68.

SELÅs, V., AND J. A. KÅLÅs. 2007. Territory occupancy rate of Goshawk and Gyrfalcon: No evidence of delayed numerical response to grouse numbers. Oecologia 153:555561.

Shank, C. C., AND K. G. Poole. 1994. Status of Gyrfalcon Falco rusticolus populations in the Northwest Territories, Canada. Pages 421-436 in B. -U. Meyburg and R. D. Chancellor (Eds.). Raptor Conservation Today. Helm Information Inc., Mountfield, East Sussex, UK.

SiIvONEN, L. 1948. Structure of short-cyclic fluctuations in numbers of mammals and birds in the northern parts of the northern hemisphere. Papers on Game Research 1:1-166.

Steen, J. B., H. Steen, N. C. Stenseth, S. Myrberget, And V. Marcström. 1988. Microtine density and weather as predictors of chick production in Willow Ptarmigan, Lagopus l. lagopus. Oikos 51:367-373.

Steenhof, K., M. N. Kochert, AND T. L. MCDONALD. 1997. Interactive effects of prey and weather on Golden Eagle reproduction. Journal of Animal Ecology 66:350-362.

Swartz, L. G., W. Walker, II, D. G. RoseNEAU, AND A. M. SPRINGER. 1975. Populations of Gyrfalcons on the Seward Peninsula, Alaska. Pages 71-75 in J. R. Murphy, C. M. White, and B. E. Harrel (Eds.). Population Status of Raptors: Proceedings of the Conference on Raptor Conservation Techniques, 22-24 March 1973, Fort Collins, Colorado. Raptor Research Foundation, Vermillion, South Dakota, USA.

TøMmeraAs, P. J. 1993. The status of Gyrfalcon Falco rusticolus research in northern Fennoscandia 1992. Fauna Norvegica Series C, Cinclus 16:75-82.

Turchin, P., A. D. TAYlor, And J. D. Reeve. 1999. Dynamical role of predators in population cycles of a forest insect: An experimental test. Science 285:1068-1071.

Watson, A., AND R. Moss. 2008. Grouse. Collins, London, UK.

Weeden, R. B., And J. B. Theberge. 1972. The dynamics of a fluctuating population of Rock Ptarmigan in Alaska. Proceedings of the International Ornithological Congress 15:90-106.

Willebrand, T., M. HöRNELL-WiLlebrand, AND L. AsMYHR. 2011. Willow Grouse bag size is more sensitive to variation in hunter effort than to variation in Willow Grouse density. Oikos 120: in press.

YDENBERG, R. C. 1987. Nomadic predators and geographical synchrony in microtine population cycles. Oikos 50:270-272. 
- NiELSEN - 